\title{
Origin, dimensions, and distribution of remobilized carbonate deposits in a tectonically active zone, Eocene Thebes Formation, Sinai, Egypt
}

Dol:

10.1016/j.sedgeo.2018.04.008

\section{Document Version}

Accepted author manuscript

Link to publication record in Manchester Research Explorer

Citation for published version (APA):

Corlett, H. J., Bastesen, E., Gawthorpe, R. L., Hirani, J., Hodgetts, D., Hollis, C., \& Rotevatn, A. (2018). Origin, dimensions, and distribution of remobilized carbonate deposits in a tectonically active zone, Eocene Thebes Formation, Sinai, Egypt. Sedimentary Geology, 372, 44-63. https://doi.org/10.1016/j.sedgeo.2018.04.008

Published in:

Sedimentary Geology

\section{Citing this paper}

Please note that where the full-text provided on Manchester Research Explorer is the Author Accepted Manuscript or Proof version this may differ from the final Published version. If citing, it is advised that you check and use the publisher's definitive version.

\section{General rights}

Copyright and moral rights for the publications made accessible in the Research Explorer are retained by the authors and/or other copyright owners and it is a condition of accessing publications that users recognise and abide by the legal requirements associated with these rights.

\section{Takedown policy}

If you believe that this document breaches copyright please refer to the University of Manchester's Takedown Procedures [http://man.ac.uk/04Y6Bo] or contact uml.scholarlycommunications@manchester.ac.uk providing relevant details, so we can investigate your claim.

\section{OPEN ACCESS}




\section{Accepted Manuscript}

Origin, dimensions, and distribution of remobilized carbonate deposits in a tectonically active zone, Eocene Thebes formation, Sinai, Egypt

Hilary Corlett, Eivind Bastesen, Rob Gawthorpe, Jesal Hirani, David Hodgetts, Cathy Hollis, Atle Rotevatn

PII: S0037-0738(18)30113-1

DOI: doi:10.1016/j.sedgeo.2018.04.008

Reference: SEDGEO 5337

To appear in:

Received date: 26 February 2018

Revised date: 28 April 2018

Accepted date: 30 April 2018

Please cite this article as: Hilary Corlett, Eivind Bastesen, Rob Gawthorpe, Jesal Hirani, David Hodgetts, Cathy Hollis, Atle Rotevatn, Origin, dimensions, and distribution of remobilized carbonate deposits in a tectonically active zone, Eocene Thebes formation, Sinai, Egypt. The address for the corresponding author was captured as affiliation for all authors. Please check if appropriate. Sedgeo(2018), doi:10.1016/j.sedgeo.2018.04.008

This is a PDF file of an unedited manuscript that has been accepted for publication. As a service to our customers we are providing this early version of the manuscript. The manuscript will undergo copyediting, typesetting, and review of the resulting proof before it is published in its final form. Please note that during the production process errors may be discovered which could affect the content, and all legal disclaimers that apply to the journal pertain. 
Origin, dimensions, and distribution of remobilized carbonate deposits in a tectonically active zone, Eocene Thebes Formation, Sinai, Egypt

Hilary Corlett $^{1,2}$, Eivind Bastesen ${ }^{3}$, Rob Gawthorpe ${ }^{3}$, Jesal Hirani ${ }^{1,4}$, David Hodgetts ${ }^{1}$, Cathy Hollis $^{1}$, and Atle Rotevatn ${ }^{3}$

${ }^{1}$ School of Earth, Atmospheric and Environmental Sciences, University of Manchester, Oxford Road, Manchester, M13 9PL, England

${ }^{2}$ Current address: Alberta Geological Survey, 402, Twin Atria Building, 4999 - 98 Avenue,

Edmonton, Alberta, T6B 2X3, Canada

${ }^{3}$ Department of Earth Science, University of Bergen, P.O.Box 7803, Bergen, N-5020, Norway

${ }^{4} 36$ Pine Grove, Hoole, Chester, Cheshire, CH2 3LE, England 


\section{ABSTRACT}

Determination of the distribution and mechanism for carbonate-dominated mass transport sediments is often compromised by the scale and access to exposures. Consequently, many studies lack the resolution to capture the heterogeneity and dimensions of mass transport deposits. This study documents the size, shape, and stratal assemblage of remobilized carbonates in the Eocene Thebes Formation in the Hammam Faraun Fault Block (HFFB) of western Sinai, revealing the complexities of carbonate mass transport deposits at sub-seismic scale. Present day pseudo three-dimensional exposure of the Thebes Formation in a large fault block, formed during the opening of the Gulf of Suez, allowed for lateral and down-dip measurement of slope and basinal facies in the field and from photos. Remobilized facies were digitized in the photos and evaluated using image analysis software, a technique with a wide range of applications to outcrop studies of sedimentary architecture. Debris flow deposits in the lower section of the Thebes Formation comprises clasts with differing fossil assemblages. A relative sea level rise at the start of upper Thebes Formation deposition resulted in basinal sediments comprising periodic incursions of high-density turbidite grainstones encased within a background of planktonic foraminiferal wackestones. Foraminiferal assemblages of remobilized facies imply multiple sources on the carbonate platform, demonstrating the effect of short-lived tectonism on slope instability and deposition of mass transport deposits. The results of the study confirm that tectonism associated with the Syrian Arc Fold Belt, which altered the style of basin sedimentation between Egypt and Syria, persisted into the Eocene at least as far south as Wadi Araba in the western desert and Hammam Faraun in Sinai. In addition, the shape, size, and extent of the two dominant remobilized facies, debris flows and grainstone turbidites are influenced by their mud-rich versus grainy compositions. Keywords: mass transport, debris flow, carbonate turbidite, Syrian Arc, remobilized carbonate 


\section{Introduction}

Increased interest in carbonate slopes over the last several decades has improved our understanding of remobilized carbonate facies (Cook et al., 1972; McIlreath, 1977; Schlager and Ginsburg, 1981; Mullins and Cook, 1986; Eberli, 1987; Della Porta et al., 2003; Collins et al., 2006; Playton et al., 2010; Mulder et al., 2012; Talling et al., 2012; Mulder et al., 2014; Betzler et al., 2014; Playton and Kerans, 2015; Reijmer et al., 2015a (and references therein); Wunsch et al., 2017; Sola et al., 2017; Jablonská et al., 2017). The results of these studies have demonstrated the wide range of morphologies in remobilized carbonate deposits, which makes them arguably more variable than and different to mass transport facies in the siliciclastic environment (Droxler and Schlager, 1985; Haak and Schlager, 1989; Coniglio and Dix, 1992; Mulder and Alexander, 2001; Payros and Pujalte, 2008; Playton et al., 2010; Janson et al., 2011; Talling et al., 2012, Reijmer et al., 2015a; Sola et al., 2017). This means that the classification of remobilized carbonate facies or predictability of stacking patterns and distribution can be difficult, and not easily compared to or classified by siliciclastic depositional models for slope environments. Studies of modern carbonate slope environments are also not ideal as analogues for ancient outcrop-scale studies as this research, with much focus on the deposits of the Bahama Bank, examines seismic-scale slope failure and transport (Jablonska et al., 2017). Studies of ancient deep-water carbonate sedimentation and the resultant facies distribution are both of academic interest and of economic importance, since slope and basinal carbonates are important hydrocarbon reservoirs (Hobson et al., 1985; Mullins and Cook, 1986; Cazzola and Soudet, 1993; Collins et al., 2006; Mulder et al., 2012).

There are several mechanisms that initiate mass transport from shallow to deeper water environments including changes in relative sea level (Yose and Heller, 1989; Reijmer et al., 
1991; Bosellini et al., 1993; Harris, 1994; Jorry et al., 2010; Puga-Bernabéu et al., 2014;

Grosheny et al., 2015), sedimentary loading with high rates of carbonate productivity in shallow water (Crevello and Schlager, 1980; Hiscott and James, 1985; Mullins et al., 1986; Grammer and Ginsburg, 1992; Asmus and Grammer, 2013; Betzler et al., 2014), tectonism (Watts and Garrison, 1986; Eberli, 1987; Burchette, 1988; Drzewiecki and Simo, 2002; Pickering and Corregidor, 2005; Yilmaz, 2006; Ielpi and Cornamusini, 2013; Sola et al., 2017) or some combination of these factors (Principaud et al. 2015; Hairabian et al., 2015), leading to slope instability and remobilization of sediment. The controls on the distribution, size and extent of carbonate mass transport facies are not well defined, but the platform-to-basin profile may be partly controlled by the carbonate factory (Reijmer et al., 2015a). The carbonate factory relies on various factors including stratigraphic age, climate and oceanographic evolution, emphasizing the importance of case studies and outcrop analogues from numerous ages and depositional settings. There can be limitations imposed by the extent and quality of exposure (Homewood and Eberli, 2000; Grammer et al., 2004) in outcrop analogues of slope and basinal carbonate environments where the entire platform is not exposed; however, a good understanding of the nature of the carbonate factory can aid in recognition of autochthonous versus allochthonous facies and the likelihood of the latter. Detailed descriptions of the characteristics of the remobilized deposits and interpretation of their source has implications for the cause of slope instability (Reijmer et al., 2015b), providing important information about relative sea level changes or tectonism within the basin.

This study examines a sub-seismic scale slope to basin succession, including remobilized carbonate bodies of the Eocene Thebes Formation, exposed along the eastern coastline of the Gulf of Suez. The Thebes Formation in Sinai, is mostly considered to represent deposition in a 
deep water environment with evidence for minor intervals of shallowing, based on the presence of fine grained textures dominated by calcareous muds and planktonic foraminifera (Abul-Nasr and Thunell, 1987; Moustafa and Abdeen, 1992; Scheibner et al., 2001; Spence and Finch, 2014). The Thebes Formation, being Eocene in age, was deposited after a period of warming known as the Paelocene-Eocene Thermal Maximum (PETM) that resulted in the loss of large frame-building organisms in the carbonate platform (Scheibner et al., 2005; Scheibner and Speijer, 2008). Most carbonate platforms at this time comprise grain-dominated ramp deposits including several genera of large benthic foraminifera, green and red alga, echinoids, and molluscs.

Our study area is in the Hammam Faraun Fault Block (HFFB), directly along strike and eastwards of an anticline at the Galala Plateaus (Fig. 1A; Scheibner et al., 2001; Scheibner et al., 2003; Höntzsch et al., 2011), where the exposed Thebes Formation was deposited in a shallow, carbonate-dominated basin that deepened to the south. The basin was one of several that formed between large NE-SW trending anticlinal ridges created during a NW-SE compressional tectonic phase associated with closure of the Neo-Tethys Ocean, known as the Syrian Arc System or Fold Belt (SAFB; Fig. 1A). During this compressional phase, a number of NE-SW trending extensional faults were reactivated, leading to reverse movement along the faults and development of anticlines with one steeply dipping limb. These anticlinal ridges acted as the “pseudo-platforms" for carbonate deposition (Moustafa and Khalil, 1995; Bosworth et al., 1999; Abd El-Motaal and Kusky, 2003; Youssef, 2003; Moustafa, 2014), with distal, slope to basinal deposits dominating at Hammam Faraun (Scheibner et al., 2001). Late Oligocene rifting, which led to opening of the Gulf of Suez (Moustafa and Abdeen, 1992; Young et al., 2003), exposed the Thebes Formation in fault blocks, allowing excellent pseudo-3D exposure to study the 
distribution and dimensions of remobilized carbonate facies. As with mass transport deposits in siliciclastic environments, outcrop analogues are essential since the direct measurement or observation of the mechanisms for transport in modern day is extremely rare, outside of laboratory experiments, which often lack the scale to properly recreate the textures and morphologies associated with the resultant facies (Talling et al., 2012).

There were several key objectives addressed in this study. Firstly, the remobilized and in situ carbonate facies were described and the possible source location and mechanisms for deposition were identified based on their textures, fossil content, morphology, and stacking patterns. Secondly, a quantitative description of the shape, size, occurrence, and distribution of remobilized carbonate deposits was generated. These data are pertinent to the identification of similar deposits in the subsurface, since this outcrop analogue lends itself to direct measurement of the remobilized carbonates facies, at a high-resolution, sub-seismic scale. Finally, the regional tectono-stratigraphic control on source material, depositional process, and distribution of facies is considered in the context of the migration and geographical extent of the SAFB. Overall the results of this study aid in better prediction of the size and distribution of remobilized transport facies in the subsurface based on their composition and their paleogeographic and tectonic setting.

\section{Geological Setting}

\subsection{Structure}

The HFFB is located on the western margin of the Sinai Peninsula along the eastern coastline of the Gulf of Suez (Fig. 1). Most of Egypt, including the Sinai Peninsula can be divided into three paleogeographic zones: the Arabo-Nubian massif, the stable shelf, and the 
unstable shelf (Youssef, 2003; Höntzsch et al., 2011a; Fig. 1A). The Arabo-Nubian massif is comprised of stable basement rocks in the south end of the country (Fig. 1A). On the stable shelf, the basement rocks are overlain by the Palaeozoic - Lower Cretaceous dominantly non-marine Nubian sandstones (Sharp et al., 2000), which are onlapped by a thick accumulation of Cretaceous to Eocene marine shales and carbonate sediments that show minor lithological variations across the region (Youssef, 2003). The same successions that were deposited on the stable shelf were also part of the unstable shelf referred to as the Syrian Arc Fold Belt (SAFB; Bosworth et al., 1999; Youssef, 2003). This belt, formed by the convergence of the African and Eurasian plates and the closure of the Neotethys (Moustafa and Khalil, 1995; Abd El-Motaal and Kusky, 2003), was active from the Late Cretaceous into the Eocene. Several breached anticlinal structures formed on the unstable shelf, creating highs and exposed plateaus within the epeiric seaway in northern Egypt (Bosworth et al., 1999; Youssef, 2003). The anticlinal ridges acted as the paleogeographic highs for shallow water carbonate deposition, whilst the basins in between, accumulated deeper water sediments (Moustafa and Khalil, 1995; Youssef, 2003; Spence and Finch, 2014). These plateaus would have been the only topographic highs in this inland seaway during the Paleocene and Early Eocene when the Thebes Formation was deposited. The anticlines formed through reactivation of older extensional faults that were generated during a period of rifting associated with the opening of the Neotethys in the late Permian (Abd El-Motaal and Kusky, 2003). Compression within the Syrian Arc was dominated by oblique strike slip and reverse movement on many of these older Permian and Jurassic aged faults (Abd El-Motaal and Kusky, 2003; Moustafa, 2014). The southernmost expression of Syrian Arc deformation in the "unstable shelf" in Egypt is the Wadi Araba fault (Moustafa and Khalil, 1995; Bosworth et al., 
1999; Höntzsch et al., 2011a), located directly eastwards, across the Gulf of Suez, from the HFFB study area.

Rifting in the Gulf of Suez and northern Egypt began again in the Late Oligocene, with the Hammam Faraun fault on the west side of the fault block forming one of the major bounding faults in the Gulf of Suez (Fig. 1). Uplift of the footwall has exposed a large (up to $550 \mathrm{~m}$ ) succession of Cretaceous to Early Eocene strata, including the Thebes Formation within the HFFB (Gawthorpe et al., 2003).

\subsection{Stratigraphy}

The exposed stratigraphy on the HFFB can be divided into three sedimentary megasequences, all of which overlie the Precambrian basement (Sharp et al., 2000; Gawthorpe et al., 2003; Fig. 2). The Nubian sandstones, which were deposited regionally throughout parts of Northern Africa and the Middle East, dominate the first megasequence. Dominantly non-marine siliciclastic deposition onto Precambrian basement rocks began possibly as early as the Cambrian but the earliest sediment recognized in the Nubian succession was deposited during the Carboniferous (Sharp et al., 2000). Deposition continued until the lower Cretaceous at which time the Tethys Ocean encroached on Northern Egypt and Sinai, creating several small shallow inland basins and initiating deposition of marine shales and carbonates (Moustafa and Abdeen, 1992; Bosworth et al., 1999; Sharp et al., 2000). The second megasequence comprises Upper Cretaceous to middle-upper Eocene carbonate dominated sediments (Sharp et al., 2000). The Cenomanian Raha Formation and Turonian Wata Formation are a mix of shale, clastics and limestone passing up into a limestone-dominated succession (Sharp et al., 2000). This thick limestone section is overlain by the Matulla Formation, an upward fining unit of sandstone and 
shale (Moustafa and Abdeen, 1992). Lime mud and planktonic foraminiferal wackestone dominate the Campanian-Maastrichtian Sudr Formation (Moustafa and Abdeen, 1992). The Cretaceous-Tertiary boundary is marked by an unconformity that is overlain by the Paleocene Esna Formation, comprising shales overlain by a fine-grained, carbonate dominated succession (Thebes, Darat and Tanka formations) that dominate the uppermost part of megasequence two. The Thebes Formation spans foraminiferal zones NP11-12/P6b/SBZ 8-9 to NP15/P11/SBZ 14 and interfingers with the Southern Galala Formation (Martini, 1970; Berggren et al., 1995; SerraKiel et al., 1998; Scheibner et al., 2001; Höntzsch et al., 2011a). Across much of the region the Thebes is dominated by planktonic foraminiferal wackestone with chert bands (Abul-Nasr and Thunell, 1987; Moustafa and Abdeen, 1992; Scheibner et al. 2001; Spence and Finch, 2014). On the HFFB, similar to the Galala Plateau region of the Eastern Desert (Scheibner et al., 2003; Hönztsch et al., 2011a), the Thebes Formation also comprises skeletal pack- to wackestones with embedded conglomerates and skeletal grainstones (Fig. 2). Allochems in the Thebes Formation comprise several genera of benthic foraminifera, planktonic foraminifera, red and green algae, and echinoid plates. There are no large framework-building organisms due to the overall warming during the Paleocene-Eocene Thermal Maximum (PETM; Scheibner et al., 2005; Scheibner and Speijer, 2008). The Darat Formation and the Tanka Formation are mostly composed of lime mud with interbedded marly layers (Moustafa and Abdeen, 1992).

Megasequence three began with the initiation of rifting and emplacement of igneous intrusions that separate the pre-rift and syn-rift deposits (Moustafa and Abdeen, 1992). The Late Oligocene-Early Miocene Gharandal Group unconformably overlies the pre-rift marine carbonates. This group includes the Abu Zenima Formation and the marginal marine clastics of the Nukhul Formation (Sharp et al., 2000; Jackson et al., 2002). The Rudeis Formation overlies 
the Nukhul Formation and represents deeper water deposition that marks the rift climax in the area (Patton et al., 1994). The transition of deeper water deposits in the Lower Rudeis to the Upper Rudeis is marked by an unconformity that is associated with uplift in the basin (Sharp et al., 2000). Finally, during the onset of movement on the Dead Sea Aqaba transform fault, evaporites of the Miocene Ras Malaab Group were deposited (Young et al., 2003).

\section{Methods}

Field data was collected using stratigraphic logging and mapping techniques, including direct measurement in the field wherever possible. Once the facies in the exposed Thebes Formation had been documented and were easily recognized by their weathering profile, bedding relationship and thickness, areas with limited or difficult access (i.e. cliffs, steep walled wadis) were logged with a laser range finder (TruPulse 200L), which was used to measure the vertical thickness of each facies. In total, 34 stratigraphic sections $(909.69 \mathrm{~m})$ were logged in the HFFB and the thickness of the sections ranged between 3.3 to $93.2 \mathrm{~m}$ with 24 sections logged directly and 10 recorded as laser logs. The measured thicknesses in the "laser logs" were corrected using Pythagoras theorem based on the average dip for the fault block to obtain the true bed thicknesses. The average dip of the fault block was obtained by taking bedding measurements at each of the logged sections.

Dimensions of remobilized carbonate facies were captured using multiple techniques. The facies occurring in the highest frequency were measured using digitized field photos and satellite imagery (Fig. 3 and 6B) and ImageJ freeware, in combination with the jPOR macro (Grove and Jerram, 2011). The jPOR macro was used to aid in quick analysis various photos. The pixel range was adjusted to automatically threshold the image to highlight the digitized portions of the 
photo, outlining the remobilized bodies. Outcrop scale photographs were annotated in the field with measurements that were obtained through the use of a laser range finder. Lateral and vertical dimensions of the most common remobilized carbonate facies were measured in cliffs at various locations that provided dimensions that were approximately parallel and perpendicular to depositional dip. These measurements were used to calibrate field photographs used in image analysis. Using ImageJ, the maximum and minimum Feret's diameter was used to measure dimensions of the remobilized carbonate geobodies. The Feret's diameter tool measures the longest distance between any two points in the object that is being measured (caliper) and the minimum Feret is the minimum caliper. The elongate nature of the remobilized facies in the Thebes Formation is ideal for this method of measurement.

Less common remobilized facies within the Thebes succession were generally measured in the field either directly on the exposure or, if inaccessible in a cliff face, using the laser range finder to obtain the width and thickness of the geobody. The methodology used for each facies type is recorded in Table 1.1.

Over 300 thin sections, taken from georeferenced field samples, were examined and photographed using a transmitted light microscope. Allochems types were identified (to genus level where possible) and documented in a spreadsheet. The abundance of allochems was visually estimated for each facies due to a large variation in grain sizes, intermittent diagenetic alteration, and sections that sampled both clasts and matrix, which caused bias and complications with point counting. The presence of certain allochems and the overall assemblages were utilized to reconstruct the origin of the remobilized facies, using Buxton and Pedley (1989), Flügel (2004), Beavington-Penney and Racey (2004), Rasser et al. (2005), Scheibner and Speijer (2009), and Hönzsch et al. (2011a). 


\section{Results-Thebes Formation Facies}

The Thebes Formation comprises eight facies and is divided in this study into two informal members, which are referred to herein as the lower and upper Thebes. Of these eight facies, two facies represent dominantly in situ or autochthonous deposition on the slope or midramp and on the basin floor or outer ramp (S-1 and B-1). The up-section change from S-1 to B-1 autochthonous facies marks the division between the lower and upper Thebes (Fig. 1B). Remobilized facies, previously been recognized in the HFFB by Sharp et al. (2010), are recognized by their geometry, texture, and sedimentary structures. The remobilized facies are referred to with facies codes R-1 to -6 and their dimensions, the morphology of each facies, and their components are described below with the results summarized in Table 1.1.

\subsection{Autochthonous facies}

\subsubsection{Foraminiferal packstones to grainstones (S-1)}

Foraminiferal packstones of this facies occur only in the lower Thebes. The packstones have undulatory upper and lower contacts and often surround or drape coarser grained, laterally discontinuous, remobilized facies. Beds are 10-30 $\mathrm{cm}$ thick and are difficult to trace through the study area, as they are rubbly and not very well cemented, so the lateral extent of individual beds is unknown (Fig. 5). They are intercalated with $1 \mathrm{~cm}$ thick beds of unconsolidated foraminiferal grainstone. The most common allochems are Nummulites and planktonic foraminifera as well as, in decreasing order of abundance, echinoid fragments, Alveolina, Discocyclina, Operculina, bryozoan fragments, red algae, sponge spicules, Miliolida, mollusc, serpulid worm tubes, and a few intraclasts (less than $1 \mathrm{~cm}$ ). Minor volumes of detrital quartz grains are also identified. 
Although most of the skeletal allochems are intact, several of the larger benthic foraminifera are fragmented. Sedimentary structures are absent except for minor horizontal grain alignment. Burrows are scarce and were only identified in thin section.

The packstones have undergone some diagenetic alteration making it impossible to absolutely discern primary porosity. Observed porosity types in this facies include intergranular, moldic and vuggy pores and fractures. Many of the foraminifera and other allochems have been recrystallized, and occasionally, only a micritic envelope remains.

\subsubsection{Autochthonous facies-Planktonic foraminiferal wackestone (B-1)}

The planktonic foraminiferal wackestone facies occur only in the upper Thebes and forms laterally continuous white cliffs, up to $30 \mathrm{~m}$ thick that are particularly well exposed in the dipslope of the footwall of the Hammam Faraun Fault (Fig. 6). This facies is commonly interbedded with thin layers of unsorted foraminiferal grainstone (Facies R-5). The basal contact of the planktonic foraminiferal wackestone facies with facies R-5 beds is sharp and the upper contact may display a bored or burrowed texture. These biogenic structures are filled in with facies R-5. Faint laminations are sometimes visible, especially in thin section, where allochems are aligned. The allochems most commonly observed in facies B-1 are planktonic foraminifera, minor Nummulites, and sponge spicules. Numerous thin $(<5 \mathrm{~cm})$ chert beds and nodules are found throughout this facies. 


\subsection{Allochthonous facies}

\subsubsection{Matrix-supported conglomerate (R-1)}

Matrix-supported conglomerate beds only occur in the lower Thebes (Figs. 1, 7) across most of the HFFB. Approximately $10 \mathrm{~km}$ southeast in Wadi Thal (Fig. 1), however, they are found in the upper part of the lower Thebes. The R-1 facies have a sharp irregular basal contact and a concave upper contact (Fig. 7), commonly encased in and draped by slope facies S-1. In a few examples it is overlain by upward-fining foraminiferal pack- to grainstones belonging to Facies R-2. One hundred and eight conglomerate geobodies were measured in the lower Thebes Formation, revealing that the bodies are 3-267 m long (along depositional dip), 2-64 m wide, and their thicknesses range from 0.3 to over $20 \mathrm{~m}$ (Table 1). Based on occurrences within the lower Thebes, the matrix-supported conglomerates comprise $31.4 \%$ of the succession recorded in stratigraphic logs. The term conglomerate is used here to describe the texture of this facies with carbonate clasts hosted in a background of carbonate matrix.

The conglomerates are poorly sorted with subangular clasts that range in size from less than $1 \mathrm{~cm}$ to $50 \mathrm{~cm}$ (Fig. 7D). The clasts generally have a skeletal pack-grainstone texture, but some rare clasts have been recrystallized and/or dolomitized, destroying any primary textures. Detrital quartz grains are common in this facies, particularly near the base of the Thebes Formation. There are at least two populations of clasts. The most common clasts contain Nummulites, Operculina, Alveolina, bryozoan fragments, echinoid fragments, red algae, biserial foraminifera, Dictyoconus, planktonic foraminifera, and Discocyclina. The composition of the second clast population includes green algae, Miliolida, serpulid worm tubes, molluses, and dasycladean algae. The principal pore types present in the clasts are moldic and vuggy (0.5-5 $\mathrm{mm})$. 
The conglomerate matrix has a foraminiferal wackestone texture with micro- and intergranular porosity, making it typically more porous than the clasts. The most common allochems in the matrix are planktonic foraminifera and Nummulites, along with minor occurrences of echinoid fragments, peloids and rare Operculina. Fractures are common in the matrix and generally follow or wrap around the edges of clasts.

\subsubsection{Allochthonous facies-Graded foraminiferal pack-to grainstone (R-2)}

The R-2 graded foraminiferal pack- to grainstone facies is observed in the lower Thebes, typically forms distinct fining-upward successions (Fig. 8), and is commonly found overlying facies R-1. In Wadi Thal (Fig. 1), this facies only occur in the uppermost part of the lower Thebes. The beds are either massive where allochems are well sorted (i.e. with a relatively uniform grain size) or normally graded with 1.5-3 cm-sized grains in the basal beds and 0.1-0.5 $\mathrm{cm}$-sized grains in the upper beds, with little to no mud matrix. Measurement of seven geobodies revealed that they extend down-dip 2-50 m, along-strike up to $100 \mathrm{~m}$ and are 0.5-6 $\mathrm{m}$ thick. These units have a sharp, irregular basal contact and a sharp, flat upper contact and constitute approximately $1.6 \%$ of lower Thebes Formation stratigraphy (Fig. 7), based on stratigraphic logs.

Allochems in this facies are commonly recrystallized but numerous genera of benthic foraminifera can be identified, including Nummulites, Alveolina, Miliolida, Operculina, Discocyclina, as well as echinoid fragments, bryozoan fragments, serpulid worm tubes, dasyclads, and few planktonic foraminifera. The R-2 facies also contains angular quartz grains and small intraclasts $(<1 \mathrm{~cm})$. Inter- and intragranular porosity in the grainstones is commonly cemented by mosaic calcite cement, and occasionally partially by quartz, but minor porosity occurs as molds, from dissolution of Nummulites and echinoid fragments, and vugs. Paleoflow 
markers (i.e. sole marks) were not observed in this facies as the bases of these beds were not exposed.

\subsubsection{Allochthonous facies-Clast-supported conglomerate (R-3)}

Facies R-3 only occurs in the uppermost part of the lower Thebes, approximately $90 \mathrm{~m}$ beneath the first occurrence of facies B-1. This facies occurs as a thin ( 0.3 to $2 \mathrm{~m})$, sheet-like bed, accounting for only $0.4 \%$ of the stratigraphic sections measured in the lower Thebes Formation. The bed can be traced downslope for up to $1 \mathrm{~km}$ and laterally for $1.5 \mathrm{~km}$. Unlike remobilized facies R-1 and R-2, this facies has a subtle scoured base and a sharp, flat, upper contact (Fig. 9).

The conglomerate is clast-supported containing sub-rounded clasts that range between 10 to $40 \mathrm{~cm}$ in diameter and are moderately sorted, with subtle normal grading and some clast imbrication. The clasts typically have a skeletal packstone and grainstone texture, in which skeletal allochems include benthic foraminfera (Miliolida, Soritinae, Nummulites, and Alveolina), dasyclad and red algae, algal filaments, and bryozoan fragments. Approximately half of the clasts in this facies appear to have undergone neomorphism of both the matrix and allochems. The clasts display minor moldic, intercrystalline, and intergranular porosity. The matrix surrounding the clasts is volumetrically minimal and typically composed of skeletal wackestone, containing planktonic foraminifera, minor benthic foraminifera (small Nummulites and Alveolinids) and serpulid worm tubes. The matrix also displays meso-interparticle porosity. 


\subsubsection{Allochthonous facies-Dasycladean foraminiferal grainstone (R-4)}

This facies is found near the top of the lower Thebes in the HFFB and Wadi Thal (Fig. 1B). It forms lens-shaped bodies that are usually between 1 to $3 \mathrm{~m}$ thick, 1 to $5 \mathrm{~m}$ in down-dip length, up to $10 \mathrm{~m}$ in length along depositional strike and are primarily composed of foraminiferal packstone to grainstone (Fig. 10). The grainstone texture is the result of secondary neomorphism of mud matrix. Beds (10-30 cm thick) in this facies are contorted, with some wrapping around clasts in the center of the "fold". The upper and lower contacts of this facies are sharp and the frequency at which the slumped facies occur increases toward the top of the lower Thebes Formation. The orientation of the fold axis in the slumps is E-W, with the round edge or front of the slump pointing toward the south. This facies accounts for $4.9 \%$ of the lower Thebes Formation.

The allochems present in this facies are diverse and include benthic foraminifera (Miliolida, Alveolina, Nummulites, and Operculina), dasycladean algae, red algae, planktonic foraminifera, and fragments of echinoids, bryozoans, and molluscs (Fig. 10). As in facies R-2, some of the limestone has undergone neomorphism resulting in many recrystallized allochems. Partial dissolution of some allochems and cemented fractures in this facies resulted in moldic, vuggy, and fracture porosity.

\subsubsection{Allochthonous facies-Foraminiferal grainstone (R-5)}

The foraminiferal grainstone facies occurs in the upper Thebes Formation and contains fine-grained, angular quartz grains and rounded grains of glauconite. Thirty-one geobodies of unsorted foraminifera grainstone were measured in the upper part of the Thebes Formation. The geobodies are laterally continuous along strike and dip, ranging between 57 to $940 \mathrm{~m}$ (Fig. 3). 
Accumulations of unsorted foraminiferal grainstone can be 0.5 to $10 \mathrm{~m}$ thick (Fig. 11). The foraminiferal grainstones alternate with thick (up to $30 \mathrm{~m}$ ) intervals of facies B-1, basinal wackestones (Fig. 6), and infill burrows at the top of facies B-1 (if present) at its basal contact. The upper contacts of Facies R-5 are sharp and planar and bedding is massive, with minor instances of parallel stratification. This facies comprises $26.2 \%$ of the strata within the upper Thebes.

The fauna in this facies are diverse with many genera of large benthic foraminifera (e.g. small and large Nummulites, Alveolina, Miliolida, Operculina, Dictyoconus, and Discocyclina; Fig. 11) and other biota such as echinoid, red algal, and bryozoan fragments, dasycladean, green algae, and few planktonic foraminifera. This unit has undergone some neomorphism and many of the allochems have been recrystallized and in some cases even been replaced with silica. Little or no mud is seen within Facies R-5, which is very porous and displays moldic, intergranular, intragranular, vuggy and fracture pore types (Fig.11C-D). In some occurrences of this facies, there are flute marks visible on the base of bed, which are orientated NNW to SSE and there are also several intervals with injection structures at bed bases. These grainstone "dykes" are sourced from beds of facies R-5 and appear to have been injected into the basinal planktonic foraminifera wackestone. The diameters of the dykes in outcrop are between 2 to $40 \mathrm{~cm}$ and they vary in length but can be up to $10 \mathrm{~m}$ long. The paths of these dykes are often sharply irregular within their host basinal wackestone facies. Diagenetic silicification is common within the dykes. Locally, beds of Facies R-5 show minor (sub-meter scale) offsets indicative of syn-depositional faulting (Fig. 11B). 


\subsubsection{Dasycladean Miliolid grainstone (R-6)}

This facies occurs in the upper Thebes, has a foraminifera grainstone texture. Facies R-6 accumulates within discrete bodies with scoured basal and sharp upper contacts within the surrounding in situ basinal wackestones of Facies B-1. Six of these geobodies were recognized and measured in the upper Thebes Formation. In cross-section beds along-strike are 3 to $5 \mathrm{~m}$ thick and 8 to $20 \mathrm{~m}$ thick (Fig. 12A). Downdip measurements were not possible due to the sporadic nature of exposures of this facies in cliff and wadi walls. This facies comprises less that $0.1 \%$ of the strata within the upper Thebes.

Allochems in facies R-6 include: benthic foraminifera (e.g. Nummulites large and small, Miliolida, Alveolina, Soritinae, Operculina, and Discocyclina) dasycladean algae, red and green algae, serpulid worm tubes, echinoid, bryozoan, and mollusc fragments (Fig. 12 B-C). Internally, this facies exhibits lateral-accretionary surfaces, and displays some grading with clasts at the base. Flute casts and tool marks are visible on the base of selected beds and indicate transport of sediment from a northerly (NNW) direction. The grainstones have undergone neomorphism and recrystallization of allochems is common.

\section{Discussion}

\subsection{Depositional Setting}

Allochems typical of an upper platform environment (e.g. miliolids, dasycladean algae) were only recognized in the remobilized deposits and were not observed elsewhere in the HFFB or in surrounding areas (Fig. 13; Allam and Khalil, 1988; Moustafa and Abdeen, 1992; Bastesen and Rotevatn, 2012; Spence and Finch, 2014). This complicates the reconstruction of the platform-to-basin profile. The NNW to SSE paleoflow indicators in R-5 and -6, suggest that the 
remobilized sediment in the HFFB may have been derived from proximal facies NNW of the HFFB. The relative uplift of the HFFB has exposed the part of the Thebes Formation but immediately north of the study area, the Thebes remains in the subsurface.

Directly west of the HFFB, across the Gulf of Suez in the North and South Galala Plateaus, Scheibner et al. (2000, 2003), Scheibner and Speijer (2008), Höntzsch et al. (2011a), and document shallow platform allochems and carbonate facies in the Southern Galala Formation (SGF) and the Thebes Formation in the Northern Galala Plateau, that are represented in the remobilized deposits at the HFFB. The SGF interfingers with the Thebes Formation in the Galala Plateaus. Höntzsch et al. (2011a) interpret a carbonate ramp in the Galala Plateaus with preservation of inner (SGF \& Thebes), mid- and outer ramp facies (Thebes) at this location (Fig. 13). The Eocene carbonate ramp in the Galala Plateaus was estimated to have a dip of $0.02^{\circ}$, based on an estimated $100 \mathrm{~km}$ length from upper to outer ramp along depositional dip and paleowater depths of between 100-200 m (Salem et al., 1998; Höntzsch et al., 2011a). With the presence of the Wadi Araba gap ( $\sim 40 \mathrm{~km}$ across; Fig. $13 \& 14)$, the depositional profile is incomplete in the Galala Plateaus, so this reconstruction and ramp interpretation may be inaccurate. There is insufficient exposure at both sites to be certain, although carbonate ramps are common after the PETM due to a lack of large frame-building allochems. The anticlinal ridge associated with the Wadi Araba fault (Fig. 14), which was exposed during the Paleocene (Moustafa and Khalil, 1995), must have been submerged throughout the Eocene, based on its assemblage of marine allochems. Folding associated with the SAFB affected underlying Cretaceous rocks in the North and South Galala Plateaus, giving them a steep SE side, but these structures are unconformably overlain by flat lying or near horizontal Eocene rocks. In general, as with many studies of ancient slope environments, it is difficult to determine the exact profile 
of the carbonate platform. The geometry, composition, and sedimentary structures of the remobilized facies provide information on the source, which is not visible in the study area. Given the incomplete nature of the depositional profile in this and the Galala Plateaus the depositional profile is discussed in the following sections using the generic designation of carbonate platform, and the source for remobilized deposits will be herein referred to as the upper, middle, or lower platform.

\subsection{Allochthonous Facies Interpretations}

The allochthonous facies in the Thebes Formation in the HFFB are consistent with remobilization of sediment within debrites, turbidites and plastically deformed slumped debrites. The interpretation for source (on the carbonate platform) and transport mechanism for each of

the allochthonous, remobilized facies (R-1 to 6) is discussed below and summarized in Table 1.1. In alignment with rationale of Talling et al. (2012), very few direct observations of active mass transport deposition have been made and the scale of laboratory experiments is generally insufficient, therefore, the interpretations in the following section are based on the nature of the deposits described in the Results section of this paper (i.e. upper and lower contacts, allochem composition, and sedimentary structures).

\subsection{Autochthonous Facies Interpretation}

\subsubsection{Facies $S$-1}

The foraminiferal pack-grainstone facies in the lower Thebes is interpreted as being deposited below fair weather wave base but above storm wave base. The presence of some shallow water foraminifera genera and algae can be explained by redeposition of unconsolidated 
sediments through storm events, or through wave-or tide induced currents (Jorry et al., 2006). Further evidence for transported allochems is their horizontal alignment (Beavington-Penney et al., 2005). These thin $(1 \mathrm{~cm})$ storm or wave-agitated beds intercalated with the thicker $10 \mathrm{~s} \mathrm{~cm}$ packstone beds composed of mud, with planktonic foraminiera and Nummulites are consistent with deposition on the middle platform.

\subsubsection{Facies $B-1$}

The abundance of planktonic foraminifera, lack of any allochems typical of a shallow water environment, and the fine-grained muddy texture of this facies suggest deposition in a low energy, basinal environment, beneath storm weather wave base (Buxton and Pedley, 1989). In thin section, the rare alignment of planktonic foraminifera indicates the presence of weak planar laminations in few samples, which are not visible in outcrop due to the homogeneous, finegrained nature of the sediment. Lack of any sedimentary structures in most samples of B-1 implies that this fine-grained material was deposited through suspension and traction currents in a low to medium energy environment (Eberli, 1987; Talling et al., 2012; Ielpi and Cornamusini, 2013). Burrows or borings are recognized and infilled by facies R-5 at the upper contact. The diameter of the burrows, their branching nature, and lack of fecal material in the burrow walls is consistent with Thalassinoides burrows.

\subsubsection{Facies $R-1$}

The matrix-supported conglomeratic texture and the lenticular shape of the deposits in this facies, with sharp, irregular lower and convex upper contacts, are consistent with deposition from a debris flow (Krause and Oldershaw, 1979; Hiscott and James, 1985; Mulder and 
Alexander, 2001; Drzewiecki and Simo, 2002; Savary and Ferry, 2004; Armitage et al., 2009; Courjault et al., 2011; Talling et al., 2012). Since clasts are generally matrix-supported it appears that the matrix had enough strength to support the clasts during deposition and that transport of clasts and matrix occurred as a viscous debris flow (McIlreath and James, 1979; Cook et al., 1972; Cook, 1979; Crevello and Schlager, 1980; Haughton et al., 2009). Clasts containing dasycladean algae and Miliolida foraminfera appear to have derived from a shallow, proximal source, whilst clasts comprising Nummulites, Alveolina, Operculina, and Discocyclina foraminiferal assemblage are more typical of deeper water (Beavington-Penny et al., 2005; Scheibner and Speijer, 2009; Hönzsch et al., 2011a). The composition of the polymict clasts infers a middle platform sourced system from previously lithified sediment, with a second composition of clasts sourced from a more proximal, shallow location. Deposition of clasts implies a source of previously lithified sediment that is older than the emplacement of the debris flows themselves; however, the composition of the clasts with abundant Nummulites and Alveolina would still most likely indicate an Eocene source as the populations of these faunas only began rising after the PETM, with few occurrences of the genera before this time (Scheibner et al., 2005; Whidden and Jones 2012). The clasts may have been sourced from the Southern Galala Formation, which underlies the Thebes Formation in the Galala Plateau sections in Eastern Egypt across the Suez from the HFFB (Fig 13). The Southern Galala Formation and Thebes Formation facies interfinger in the Galala Plateaus and comprise similar facies in this area (Schiebner et al., 2001; Höntzsch et al., 2011a). The matrix surrounding the clasts must have been unconsolidated when the clasts were deposited since it surrounds the clasts. The nummulite and planktonic foraminifera assemblage of the matrix suggests a middle platform assemblage. 
The range of variation in clast and grain assemblage indicates a derivation of material along the entire carbonate platform (Reijmer et al., 2015b).

\subsubsection{Facies $R-2$}

This packstone to grainstone facies is commonly found overlying, but not scouring, the matrix-supported polymict matrix-supported conglomerate facies (R-1) in the lower Thebes, which are interpreted as debrites. Debrites are not always, but can be found in association with carbonate turbidites (Krause and Oldershaw, 1979; Coniglio and Dix, 1992; Bosellini et al., 1993; Piper et al., 1999; Mulder and Alexander, 2001; Drzewiecki and Simo, 2002; Savary and Ferry, 2004; Courjault et al., 2011; Puga-Bernabeu et al., 2014). This R-2 facies is described separately from facies R-1 as it is not always present with the R-1 facies. R-2 displays a grainsupported, fining upward texture implying that it did not travel as a cohesive unit as with facies R-1 (Haughton et al., 2009). The upward-fining signature of this facies, the grain size, and sharp, planar bed contacts are consistent with deposition from turbidity currents. Therefore this facies is interpreted as representing deposition from a dilute sediment suspension (turbidity current) along the upper surface of the debris flow (R-1 facies; Figure 4 in Talling et al., 2012). The allochem assemblage of this facies consists of, Nummulites, Alveolina, Miliolida, Operculina, Discocyclina, as well as echinoid fragments, bryozoan fragments, serpulid worm tubes, dasyclads, and few planktonic foraminifera, suggesting derivation of material from across the upper to middle platform.

\subsubsection{Facies $R-3$}

This clast-supported conglomerate facies contains clasts with an assemblage comprising 
dasycladean algae and Miliolida foraminifera that are generally found in the upper platform environment (Reijmer, 1998), suggesting that at least some of the material in this facies must have been sourced from a proximal, shallow water environment. Clast-supported conglomerates or high-density/hyper-concentrated debris flows or rock-fall of this nature have been observed in other areas (Shanmugam et al., 1996; Mulder and Alexander, 2001; Dzrewiecki and Simo, 2002). The transition from a debris flow to a hyperconcentrated debris-flow is more likely if they contain sediment larger than medium silt (Mulder and Alexander, 2001). Deposition of lithified clasts infers collapse and subsequent transport of lithified sediment. There is little to no erosion evident at the base, which is typical of hyper-concentrated debris flows that experience hydroplaning and transport of larger clasts in these types of debris flows may be able to travel farther due to the lack of a cohesive matrix (Mulder and Alexander, 2001).

\subsubsection{Facies $R-4$}

The allochems present in this facies appear to have been derived from a variety of sources but the majority of fossils are characteristic of a shallow water, proximal setting (Bauer et al., 2003; Beavington-Penny et al., 2005; Wilson, 2015) with some sediment input from a slightly deeper water setting (Operculina - Beavington-Penney et al., 2005). Several of the allochems in facies R-4 (Miliolida, Alveolina, Nummulites, Operculina, dasycladean algae, red algae, and molluscs) correlate with the assemblage noted in Hontzsch et al. (2011a). The folded and contorted nature of the beds, within lens-shaped bodies implies a plastic flow that has resulted in slumping (Martinsen, 1994; Dzrewiecki and Simo, 2002; Asmus and Grammer, 2013). The packstone to grainstone texture is unusual, since slumps are generally muddominated (Flügel, 2004 - Chapter 15). The grainstone texture appears to be a result of 
secondary neomorphism of the mud matrix in Facies R-4, which has obscured the original texture of the R-4 facies. The abundance of shallow water allochems implies that the slumps must have initiated from a proximal position, consistent with the distribution of slumped facies documented in other studies, which conclude that slumping generally occurs higher on the slope and in a more proximal position than associated debris flow and turbidite facies, suggesting a relative sea level fall in the upper portion of the lower Thebes (Eberli, 1987; Crevello and Schlager, 1980; Mulder and Cochonat, 1996; Shanmugam et al., 1996; Dzriewiecki and Simo, 2002; Armitage et al., 2009).

\subsubsection{Facies $R-5$}

Allochems present in facies R-5 appear to be sourced from shallow to intermediate water depths, likely from the upper to middle platform. Interbedding of facies R-5 with hemipelagic basinal wackestones, suggests deposition of facies R-5 by mass flow into the basin. The grainsupported texture with complete lack of mud, as well as the presence of sand injection structures, is typical of non-cohesive sediment gravity flows that have been described as highly concentrated or modified grainflows (Mullins and Neumann, 1979; Postma, 1986; Lowe and Guy, 2000; Amy et al., 2005). However, grainflows are dependent on gravity driven flow that is initiated on steep slopes, and the redeposited sediments in grainflows are usually deposited on or near the base of these slopes (Lowe et al., 1976; Lowe 1982; Grosheny et al., 2015; Ferry et al., 2015). Turbidity currents are capable of transporting sediments over slopes of less than 0.5 degrees (Mullins and Cook, 1986; Melim and Scholle, 1995; Scheibner et al., 2000; Drzewiecki and Simo, 2002). Also, a review of the grainflow concept (Dasgupta and Manna, 2011) identifies the most distinctive feature of a grain flow as particle segregation leading to inverse grading. 
Given the lack of evidence for a steep slope from studies on the west side of the Suez on Maastrichtian-Paleocene-Eocene deposits (Kuss et al., 2000; Scheibner et al., 2003; Höntzsch et al., 2011a) and the distinct lack of any grading, it is considered more likely that facies R-5 is turbiditic in origin. Sediments deposited through mass gravity flows can have larger concentrations of finer material present than facies R-5 and tend to display inverse grading if there is a variation in grain size and on the consistency of the velocity of the flow (Crevello and Schlager, 1980; Postma, 1986; Drzewiecki and Simo, 2002; Amy et al., 2005; Cartigny et al. 2013). Inverse grading is not considered characteristic of high-density turbidite deposits as it is with grainflows (Dasgupta and Manna, 2011). Haughton et al. (2009) and Cartigny et al. (2013) highlight a distinction between low-density turbidites, containing mixed mode grains that may display sedimentary structures or grading, and high-density turbidites that emplace sand or gravel sized grains. High-density calciturbidites typically contain larger grains, little matrix, and often form massive beds commonly with no apparent sorting or grading (Crevello and Schlager, 1980; Colacicchi and Baldanza, 1986; Drzewiecki and Simo, 2002; Haughton et al., 2009). Sorting in carbonate turbidites is dependent on the type of grains, the density of their skeletons and the amount of fines contained within the mass transport deposit (Hodson and Alexander, 2010). Traction structures at the base of the bed such as sole marks are also common in turbidites but not present in grain flow deposits (Amy et al., 2005). High-density turbidites can contain high water content, making escape structures such as sand injections common in clastic turbidites. There are several occurences of dykes composed of R-5 facies that have been injected into the fine-grained B-1 facies in the upper Thebes, likely caused by similar processes effecting siliciclastic turbidite facies (Postma, 1986). Based on the presence of grainstone dykes and sole marks, the dominance of massive bedding, along with a lack of supporting evidence for a steeply 
dipping slope, facies R-5 is interpreted to have been deposited from high-density turbidity currents.

\subsubsection{Facies $R-6$}

Lateral-accretionary surfaces, the nature of the scoured basal contact, and normal grading in this facies indicates that the grainstones of Facies R-6 are indicative of deposition via a confined channel flow. The size and lensoid shape of these scoured features is consistent with erosive-depositional distributary channels and possible relative sea level fall, resulting in a transition from depositional to erosive facies (Payros and Pujalte, 2008). The allochems found in this facies indicate a single, shallow water, upper platform sediment source (Dzrewiecki and Simo, 2002; Bauer et al., 2003; Flügel, 2004; Beavington-Penny et al., 2005; Höntzsch et al., 2011a; Wilson, 2015), which suggests sediment bypassing the middle platform.

\subsection{Depositional History}

The basal succession of the lower Thebes Formation in the study area is predominantly composed of the matrix-supported conglomerates (R-1) and graded pack- to grainstones (R-2) encased in a background of middle platform in situ packstones. The lensoid shape of these deposits, with a longer downslope (3-267 m) than lateral (2-64 m) horizontal distance, and lithified clasts from two different sources suggests failure of a consolidated middle to upper platform. This produced lobate debris flows, with clasts transported a short distance down the gentle slope in a slurry of finer grained sediments (Krause and Oldershaw, 1979; Hiscott and James, 1985; Payros and Pujalte 2008; Ielpi and Cornamusini, 2013). The presence of lithified carbonate clasts indicates incision into underlying strata during lower Thebes Formation 
deposition. Basal bed contacts are irregular, but not erosive, suggesting sediment transport downslope without incision of the underlying strata. Facies R-2 occasionally overlie R-1, indicating a basal flow with overlying graded sediments, likely associated with waning flow (Krause and Oldershaw, 1979; Talling et al., 2012).

The first and only occurrence of the laterally continuous clast-dominated hyperconcentrated debris flow (R-3) is approximately 90 meters below the base of the upper Thebes (Fig. 7). This deposit has been interpreted as forming through incision of underlying material and rock fall that resulted in a broadly distributed but relatively thin matrix-poor deposit. Its broad manifestation across the study area but unique occurrence in the strata suggests that it represents a significant event in basin evolution. Subsequently, deposition of debris flow units (R-1) continued, some with overlying pack- to grainstone facies (R-2), into the uppermost part of the lower Thebes Formation. Gradually, however, there is an increasing frequency and abundance of slumped pack- to grainstone facies (R-4), interpreted to represent upper platform instability and slide based on a dominantly shallow water allochem assemblage. Slumps represent coherent mass movement and may eventually evolve into debris flows (Shanmugam et al., 1996). They tend to occur father up the slope and may indicate a progressive relative sea level fall in the lower Thebes.

The transition from the lower to upper Thebes is recognized by a change in the background autochthonous facies. In particular, the foraminiferal packstone-grainstones (S-1), interpreted as being deposited above storm wave base, give way to planktonic foraminifera wackestones that were accumulated below storm wave base. High-density turbidite facies (R-5) and the channelized grainstone (R-6) deposits dominate the remobilized carbonate deposits in the upper Thebes Formation (Figs. 2, 4). The wackestone facies (B-1), dominantly comprised of 
mud with minor planktonic foraminifera, and occasional chert beds, is consistent with deposition in a lower platform to basinal setting. Overall, therefore, the lower to upper Thebes Formation transition defines a back-stepping or northward retrogradation of the carbonate platform and relative sea level rise. On the western side of the Gulf of Suez, a similar stratigraphic interval (Stage H) of "pure carbonate deposition" with basinal marls and chert nodules was observed by Höntzsch et al. (2011a) and is interpreted here to be time-equivalent to basinal wackestone facies in the upper Thebes Formation on the HFFB. Höntzsch et al. (2011a) note this retrogradation of the platform in the Galalas as taking place during the early Lutetian (NP 14b).

\subsection{Facies evidence for tectonically driven instability on the carbonate platform}

Instability and mass transport on carbonate platforms can be the result of oversteepening or pore-water over pressure (e.g. Crevello and Schlager, 1980; Hiscott and James, 1985; Mullins and Cook, 1986; Grammer and Ginsburg, 1992; Spence and Tucker, 1997; Asmus and Grammer, 2013), eustatically controlled sea level fluctuations (e.g. Yose and Heller, 1989; Reijmer et al., 1991; Harris, 1994; Jorry et al., 2010; Puga-Bernabéu et al., 2014), or tectonism (e.g. Watts and Garrison, 1986; Eberli, 1987; Burchette, 1988; Pickering and Corregidor, 2005; Yilmaz, 2006; Ielpi and Cornamusini, 2013; Hairabian et al. 2015), or a combination of these factors (e.g. Dolan, 1989; George et al., 1995; Gawenda et al., 1999; Drzewiecki and Simo, 2002; Wilson et al., 2012; Reijmer et al. 2015b). The importance of these factors on sediment source and the dimensions of slope or mid-ramp deposits are considered here in the context of the palaeogeography, paleoclimate, and tectonic regime.

The absence of frame-builders after the Paleocene-Eocene Thermal Maximum (PETM) and resultant dominance of large benthic foraminifera together with the probability of a 
corresponding ramp profile, as cited in the Galala Plateaus area (Scheibner et al. 2000; Scheibner et al. 2003; Scheibner and Speijer, 2008; Höntzsch et al. 2011a) make collapse due to oversteepening of a margin at HFFB unlikely. Furthermore, the composition of the clasts in facies R-1 in the Thebes Formation is polymict, indicating derivation of material from both the inner and middle platform.

The Thebes Formation, which is deposited into the Middle Eocene (Moustafa and Abdeen, 1992; Höntzsch et al., 2011a), would have experienced second order fluctuations in eustatic sea level (Haq et al., 1988; Miller et al., 2005) and an overall regression. The transition in the autochthonous facies in the lower to upper Thebes Formation from Nummulite wackestone (S-1) to plantonic foraminiferal wackestone (B-1) implies a relative sea level rise affecting the platform. In addition, the predominance of matrix-supported conglomerates (R-1) and associated grainstone (R-2) in the lower Thebes Formation passing into aerially extensive grainstones (R-5) suggests a transition from a more proximal to a more distal location, though there are other controls on the distribution of reworked sediment. Similar changes in relative sea level are observed in stages $\mathrm{G}$ to $\mathrm{H}$ in Höntzsch et al. (2011a; 2011b). Stage G shows evidence for a deepening at the mid ramp and $\mathrm{H}$, a transition from mixed siliciclastic deposition attributed to uplift along the Wadi Araba fault associated with the SAFB to pure carbonate deposition, signaling cessation of tectonism. A similar change at HFFB, including the disappearance of any quartz grains that were present in the lower Thebes facies, to wholly carbonate facies in the upper Thebes mirrors the transition that was observed in the Galalas. The cessation in movement along the Wadi Araba fault may have resulted in a change in overall slope of the carbonate platform, which is reflected in the overall change from dominantly coherent and plastic mass 
movement in the lower Thebes to fluidal movement in the upper Thebes (Shanmugam et al. 1996; Armitage et al., 2009)

The timing of compressional tectonics associated with the SAFB has been debated (Bosworth et al., 1999), but stratigraphic and structural studies of inversion faults that are typical of SAFB deformation have revealed that compression must have continued into Middle Eocene or even as recently as the Oligocene (Moustafa, 2013). Given the tectonic influence of the SAFB's persistence into the Early Eocene (Bosworth et al. 1999; Moustafa, 2014; El Ayyat and Obaidalla, 2016), causing relative sea level changes decoupled from eustasy, and the polymict composition of facies R-1 to -6 , tectonism is considered the most likely cause for slope instability observed at the HFFB (Reijmer et al., 2015b). Additionally, the slope of the carbonate platform or ramp in the Galala Plateau area is estimated at only $0.02^{\circ}$ (Höntzsch et al., 2011a). A tectonic trigger for slope instability may explain why such a large volume of reworked sediment was deposited on the slope. Although not able to be correlated using biostratigraphy, Höntzsch et al. (2011a) note that their study Area 1, in the North Galala Plateau NNW of the Wadi Araba fault, hosts the only autochthonous inner ramp facies, containing soritids, green algae, and molluscs, and the area SSE of the fault (Areas 3-5) are "dominated by hemipelagic marls and allochthonous relocated platform allochems". The SAFB tectonism active in this region was compressional and perpendicular to the direction of sediment transport onto the slope. It is unlikely that this volume of sediment, seen in the Galalas and in the HFFB, particularly the gravity-driven debris flow facies (R-1), would result on such a shallow slope without tectonic influence. 


\subsection{Implications for SAFB Tectonism}

The southernmost expression of Syrian Arc deformation on the unstable shelf is the Wadi Araba fault. Wadi Araba, which is located directly east, and along depositional strike, of the HFFB separates the Northern and Southern Galala plateaus in the Eastern Desert. Scheibner et al. (2003) refer to this structure here as a "half-graben" that has experienced footwall uplift, causing subsidence in the hanging wall, creating accommodation space in the Southern Galala. Other structural studies in areas affected by the SAFB in this area refer to the Wadi Araba structure as an inversion fault and breached anticline that results in a monoclinal structure, with the Southern Galalas dipping toward the SE (Fig. 14; Moustafa and Khalil, 1995; Bosworth et al., 1999; El Ayyat and Obaidalla, 2016). An angular unconformity and steeply dipping beds are exposed in the northern section of the Southern Galala Plateau, providing evidence for late Santonian folding related to movement along the Wadi Araba fault by Syrian Arc deformation (Moustafa and Khalil, 1995). Paleocene rocks are missing in the northern part of the Southern Galalas Plateau but are present in the northern portion of the North Galalas Plateau and southern cliffs of the South Galalas Plateau (Fig. 14 - A-A'; Moustafa and Khalil, 1995). The missing strata suggest that the breached anticline associated with the Wadi Araba fault was exposed during the Paleocene and carbonate deposition took place offshore of this structural high (Fig. 14).

The faulting associated with the SAFB visible in the Galala Plateaus (Wadi Araba Fault) was not observed at the HFFB but a similar style of Cretaceous inversion folds, also unconformably overlain by flat-lying middle Eocene rocks, are present in areas north of the study area (Moustafa and Khalil, 1995; Moustafa, 2014). In addition, Moustafa and Khalil (1995) and Bosworth et al. (2012) document an offshore structure west of the HFFB that may be associated with the Wadi Araba Fault. It is located in the hanging wall strata that were 
downthrown during the opening of the Gulf of Suez. Remobilized facies at HFFB may provide evidence that the Wadi Araba Fault, the offshore structure, and the anticlinal ridge at Gebel Somar are connected (Fig. 13), as postulated by Moustafa and Khalil (1995).

The study by Höntzsch et al. (2011a) cite the occurrence of remobilized carbonate facies in the Thebes Formation in the Galala Plateaus as evidence for syn-sedimentary tectonism in the Eocene associated with the Syrian Arc Fold Belt (SAFB) and the transition into "basinal marls" in the upper part of the Thebes Formation as the termination of movement along the Wadi Araba fault. There were also no resedimentaed deposits observed in the North Galala Plateau, northwest of the fault (Höntzsch et al. 2011a). Given the abundance of remobilized carbonate deposits housed in a background of slope packstones (S-1) within the lower Thebes in the HFFB, and more importantly, their polymict clast and allochem assemblage, a similar process is proposed here; however, the nature of faulting is interpreted in this study as compressional, consistent with other breached anticlines found throughout areas affected by SAFB tectonism. The frequency of meter-scale, laterally continuous, debris flow deposits (R-1) with cobble-grade clasts derived from multiple locations on the platform indicates several intervals of slope instability and collapse (Reijmer et al., 2015b), followed by waning flow indicated by the occurrence of overlying turbidite beds (R-2) observed in some, but not all occurrences of facies R-1. The contact between the lower and upper Thebes Formation is preceded by the deposition of a broadly distributed clast-supported conglomerate, interpreted as a debris sheet flow (R-3). The unique occurrence of this body suggests a single event catastrophic collapse attributed to fault reactivation during the waning phases of SAFB migration. The nature of the mass transport deposits in the upper Thebes at HFFB and the surrounding basinal B-1 facies suggest deposition in a more distal environment. Evidence for minor synsedimentary faulting within the upper 
Thebes Formation (Fig. 11B) at HFFB, supported by a lack of brittle deformation, suggest persistent minor tectonic activity along the Wadi Araba Fault and related structures into the early Middle Eocene, during the last stages of Thebes Formation deposition.

\subsection{Extent of remobilized carbonate facies}

The orientation of the basins created through SAFB compression along northeast to southwest oriented faults is northwest to southeast (Bosworth et al., 1999). Therefore, remobilized carbonate facies in the HFFB study area would be expected to dissipate toward the southeast. Approximately $10 \mathrm{~km}$ southeast of the northern extent of the HFFB in Wadi Thal, remobilized carbonate facies R-1, 2, and 4 are only present in the upper part of the lower Thebes Formation and there is no evidence for mass transport in the basal portion of the lower Thebes or in the upper Thebes Formation at this location (Fig.13). There is also a change in overall thickness of the Thebes Formation from $350 \mathrm{~m}$ at HFFB to $\sim 180$ meters at Wadi Thal, possibly reflecting an increased level of compaction of fine-grained deeper water sediments and decrease in the thickness of resedimented strata at this location. Another $12 \mathrm{~km}$ southeast of Wadi Thal (22 km SW of the HF study area), the Thebes Formation has been described as "deep-water micritic deposit with abundant chert bands" (Fig. 1; Bastesen and Rotevatn, 2012). A study of the Thebes Formation by Spence and Finch (Fig.13; 2014) approximately $15 \mathrm{~km}$ ESE of the HFFB in Wadi El Iseila describes the Thebes Formation as comprising uniformly thin-bedded, fine-grained planktonic foraminiferal wackestone-packstone with interbedded nodular chert with no mention of remobilized facies. Finally, Allam and Khalil (1988) document exposures of Thebes Formation further south in the Gebel Qabeliat Area as chalky limestones with chert interbeds. These descriptions of distal facies in the Thebes Formation south and southeast of the 
HFFB implies that the basin deepened to the SE (Kuss et al., 2000; Spence and Finch, 2014) and the maximum southeasterly extent of mass transport deposits in the middle to lower platform is somewhere between $10 \mathrm{~km}$ (Wadi Thal) from HFFB, where remobilized facies were still present, and $22 \mathrm{~km}$ (Wadi El Iseila; Fig. 1), where no remobilized facies were recorded. The distance from the HFFB middle platform to the shallow source area is unknown due to limited accessibility to exposures but may have initially been located along WSW-ENE strike of Wadi Araba and Gebel Somar structures ( $20 \mathrm{~km}$ NW of HFFB; Fig. 13) during deposition of the lower Thebes Formation.

\subsubsection{Size and distribution of individual facies}

One of the most striking differences in the size and shape of remobilized facies is that between the two most common facies in the lower and upper Thebes Formation, which are facies R-1 and R-5, respectively (Fig. 3D). The lateral extent of individual lobes of the R-1 facies only reaches a maximum of less than $300 \mathrm{~m}$ with highly variable sediment thicknesses, whereas facies R-5 was measured as anywhere between 50 to $1000 \mathrm{~m}$ with fairly uniform thickness. The debrisflows move as a viscous, sediment-water laden mass with some degree of cohesion, giving them their lobate shape (Pratson et al., 2000). Facies R-5, deposited via turbidity currents, is characteristically more laterally continuous along the basin floor with minimum thickness variation (Crevello and Schlager, 1980). Grains in facies R-5 would have been unconsolidated during transport, as evidenced by their depositional texture and infill of borings at the upper contact of facies B-1 with overlying R-5 facies. R-5 therefore would have acted as a cohesionless mass unlike debris flow facies R-1. This grainy mixture is carried by fluid turbidity, providing greater mobility along with exchange of water between sediment, unlike the mud-rich 
debris flows (Pratson et al., 2000). The only occurrence of debris sheet facies R-3 demonstrates similar lateral continuity and minimal thickness variation seen in facies R-5, likely also attributed to the lack of mud and greater sediment-water exchange in both of these facies compared to R-1. Transport of clasts in largely matrix free deposits are more likely to travel over long distances, without eroding or scouring the underlying facies (see Table 1.1) because, according to Mulder and Alexander (2001), particles are more easily moved without a matrix that would prevent upward movement.

\section{Conclusions}

The excellent 3D exposure of remobilized carbonate deposits in the Eocene Thebes Formation provided information regarding the shape, size, source, and distribution of remobilized carbonate deposits (Table 1.1) on a sub-seismic scale. Slope instability in the area is attributed to tectonism along the SAFB, based on the presence of lithified polymict clasts and unconsolidated material sourced from multiple locations on the carbonate platform. The trigger of slope instability and nature of sediment (i.e. slurry of mud-rich matrix and clasts, versus unconsolidated grains) contributed to the dimensions and morphology of the resulting remobilized facies, and their localized distribution within Sinai.

The remobilized facies (R-1 to -6) must be considered in context of the background in situ facies (S-1 and B-1) to determine their position on the carbonate platform after deposition, and the constituents of the remobilized facies (i.e. allochems) can aid in determination of source and the mechanism for mass transport. Description and measurement of the slope and basinal facies in the HFFB revealed: 
- Six types of remobilized carbonate facies (R-1 to -6) contained within two background autochthonous facies (S-1 and B-1).

- A retrogradation of the carbonate ramp was recognized by a change in the characteristics that defined the autochtonous facies from a slope to a basinal environment. This change defined two unofficial members of the Thebes Formation referred to in this paper as the lower and upper Thebes Formation.

- Localized mass transport facies containing lithified, polymict clasts, coupled with the tectonic history of the region imply slope instability and remobilization of material was due to reactivation of the Wadi Araba fault, with one catastrophic event, resulting in mass transport facies R-3.

- Matrix-poor facies such as R-3 and R-5 are thinner and more laterally extensive than the most common Thebes facies R-1, a matrix-supported conglomerate. This lack of matrix has allowed for larger aerial distribution of grains/allochems and previously lithified clasts. The lobate shape of facies R-1 reflects the en masse freezing of mud-rich debris flow. Facies R-4 also displays lobate shapes and minimal lateral extent. They appear grain-supported but matrix in the facies has been neomorphosed so it is difficult to distinguish the matrix from allochem fragments, also present in this facies.

These results provide evidence for continued tectonic activity in Sinai until at least the end of the Early Eocene and also a possible connection between the Wadi Araba fault, offshore structure, and anticlinal ridge at Gebel Somar. As the Wadi Araba Fault and associated structures are considered to be one of most southern expressions of the SAFB in the region, evidence for syn-sedimentary faulting during deposition of the upper Thebes Formation has implications 
regarding the southern extent and timing of activity along all of the fault-related shallow inland basins affected by the SAFB from Egypt to Syria.

\section{Acknowledgements}

Several generous sponsors made this work possible. BG Group, Saudi Aramco, Statoil, and Total are thanked for their generous support. We would also like to acknowledge Richard Newport, Anja Eker, Michael Laukemann, Craig Lowe, and Eagle of the Desert outfitters for their help in the field. Two anonymous reviewers are thanked for their considerate and helpful reviews that greatly improved the paper. 


\section{References}

Abd El-Motaal, E., Kusky T.M. 2003. Tectonic evolution of the intraplate S-shaped Syrian Arc Fold-Thrust Belt of the Middle East Region in the context of plate tectonics. In: The Third International Conference on the Geology of Africa, 2, 139-157.

Abul-Nasr, A., Thunell. R.C. 1987. Eocene eustatic sea level changes, evidence from Western Sinai, Egypt. Palaeogeography, Palaeoclimatology, Palaeoecology, 58, 1-9.

Allam, A., Khalil, H. 1988. Geology and stratigraphy of the Arif EL-Naqa area, Sinai, Egypt. Egyptian Journal of Geology, 32, 199-218.

Amy, L. A., Talling, P. J., Peakall, J., Wynn, R. B., Thynne, R. A. 2005. Bed geometry used to test recognition criteria of turbidites and (sandy) debrites. Sedimentary Geology, 179, 163-174.

Armitage, D. A., Romans, B. W., Covault, J. A., Graham, S. A. 2009. The influence of masstransport-deposit surface topography on the evolution of turbidite architecture: the Sierra Contreras, Tres Pasos formation (Cretaceous), southern Chile. Journal of Sedimentary Research, 79, 287-301.

Asmus, J. J., Grammer, G. M. 2013. Characterization of deepwater carbonate turbidites and mass-transport deposits utilizing high-resolution electrical borehole image logs: Upper Leonardian (Lower Permian) Upper Bone Spring Limestone, Delaware Basin, Southeast New 
Mexico and West Texas. Gulf Coast Association of Geological Societies Transactions, ssepis 63 , $27-65$.

Bastesen, E., Rotevatn, A. 2012. Evolution and structural style of relay zones in layered limestone-shale sequences: insights from the Hammam Faraun Fault Block, Suez rift, Egypt. Journal of the Geological Society, London, 169, 477-488.

Bauer, J., Kuss, J., Steuber, T. 2003. Sequence architecture and carbonate platform configuration (Late Cenomanian-Santonian), Sinai, Egypt. Sedimentology, 50, 387-414.

Beavington-Penny, S.J., Racey, A. 2004. Ecology of extant Nummulitids and other larger benthic foraminifera, application in palaeoenvironmental analysis. Earth Science, 67, 219265.

Beavington-Penney, S.J., Wright, V.P., Racey, A. 2005. Sediment production and dispersal on foraminifera-dominated early Tertiary ramps: the Eocene El Garia Formation, Tunisia. Sedimentology, 52, 537-569.

Berggren, W. A., Kent, D. V., Swisher, C. C., III, and Aubry, M.P. 1995. A revised cenozoic geochronology and chronostratigraphy. In "'Geochronology Time Scales and Global Stratigraphic Correlation,', SEPM Special Publication Vol. 54, pp. 129-212. 
Betzler, C., Lindhorst, S., Eberli, G.P., Lüdmann, T., Möbius, J., Ludwig, J., Schutter, I., Wunsch, M., Reijmer, J.J., Hübscher, C. 2014. Periplatform drift: The combined result of contour current and off-bank transport along carbonate platforms. Geology, 42, 871-874.

Bosellini, A., Neri, C., Luciani, V. 1993. Platform margin collapses and sequence stratigraphic organization of carbonate slopes: Cretaceous-Eocene, Gargano Promontory, Southern Italy. Terra Nova, 5, 282-297.

Bosworth, W., Guiraud, R., Kessler, L.G. 1999. Late Cretaceous (ca. 84 Ma) compressive deformation of the stable platform of northeast Africa (Egypt): Far-field stress effects of the "Santonian event" and origin of the Syrian arc deformation belt. Geology, 27, 633-636.

Bosworth, W., Khalil, S., Clare, A., Comisky, J., Abdelal, H, Reed, T., Kokkoros, G. 2012. Integration of outcrop and subsurface data during the development of a naturally fractured Eocene carbonate reservoir at the East Ras Budran concession, Gulf of Suez, Egypt. Geological Society, London, Special Publications, 374, 333-360.

Burchette, T. P. 1988. Tectonic control on carbonate platform facies distribution and sequence development: Miocene, Gulf of Suez. Sedimentary Geology, 59, 179-204.

Buxton, M. W. N., Pedley, H. M. 1989. Short Paper: A standardized model for Tethyan Tertiary carbonate ramps. Journal of the Geological Society, 146, 746-748. 
Cartigny, M. J., Eggenhuisen, J. T., Hansen, E. W., Postma, G. 2013. Concentration-dependent flow stratification in experimental high-density turbidity currents and their relevance to turbidite facies models. Journal of Sedimentary Research, 83, 1047-1065.

Cazzola, C., Soudet, H.J. 1993. Facies and reservoir characterization of Cretaceous-Eocene Turbidites in the Northern Adriatic. Generation, Accumulation and Production of Europe's Hydrocarbons III. Special Publication of the European Association of Petroleum Geoscientists, 3, p.19.

Colacicchi, R., Baldanza, A. 1986. Carbonate turbidites in a Mesozoic pelagic basin: Scaglia Formation, Apennines - comparison with siliciclastic depositional models. Sedimentary Geology, 48, 81-105.

Collins, J. F., Kenter, J. A. M., Harris, P. M., Kuanysheva, G., Fischer, D. J., Steffen, K. L. 2006. Facies and reservoir-quality variations in the late Visean to Bashkirian outer platform, rim, and flank of the Tengiz buildup, Precaspian Basin, Kazakhstan, in P. M. Harris and L. J. Weber, eds. Giant hydrocarbon reservoirs of the world: From rocks to reservoir characterization and modeling: AAPG Memoir 88/SEPM Special Publication, p. 55 -95.

Coniglio, M., Dix, G.R. 1992. Carbonate slopes, in R. G. Walker and N. P. James, eds., Facies models: response to sea level change: Geological Association of Canada, p. 349-373. 
Cook, H.E., McDaniel, P.N., Mountjoy, E.W., Pray, L.C. 1972. Allochthonous carbonate debris flows at Devonian Bank ('reef') margins, Alberta, Canada. Bulletin of Canadian Petroleum Geology, 20, 439-497.

Cook, H.E. 1979. Ancient continental slope sequences and their value in understanding modern slope development. SEPM Special Publication, 27, 287-305

Courjault, T., Grosheny, D., Ferry, S., Sausse, J. 2011. Detailed anatomy of a deep-water carbonate breccia lobe (Upper Jurassic, French subalpine basin). Sedimentary Geology, 238, $156-171$.

Crevello, P.D., Schlager, W. 1980. Carbonate debris sheets and turbidites, Exuma Sound, Bahamas. Journal of Sedimentary Petrology, 50, 1121-1147.

Dasgupta, P., Manna, P. 2011. Geometrical mechanism of inverse grading in grain-flow deposits: An experimental revelation. Earth-Science Reviews, 104, 186-198.

Della Porta, G., Kenter, J. A., Bahamonde, J. R., Immenhauser, A., Villa, E. 2003. Microbial boundstone dominated carbonate slope (Upper Carboniferous, N Spain): microfacies, lithofacies distribution and stratal geometry. Facies, 49, 175-207.

Dolan, J. F. 1989. Eustatic and tectonic controls on deposition of hybrid siliciclastic/carbonate basinal cycles: discussion with examples. AAPG Bulletin, 73, 1233-1246. 
Droxler, A.W., Schlager, W. 1985. Glacial versus interglacial sedimentation rates and turbidite frequency in the Bahamas. Geology, 13, 799-802.

Drzewiecki, P.A., Simo, J.A. 2002. Depositional processes, triggering mechanisms and sediment composition of carbonate gravity flow deposits: examples from the Late Cretaceous of the south-central Pyrenees, Spain. Sedimentary Geology, 146, 155-189.

Eberli, G.P. 1987. Carbonate turbidite sequences deposited in rift-basins of the Jurassic Tethys Ocean (eastern Alps, Switzerland). Sedimentology, 34, 363-388.

El Ayyat, A. M., Obaidalla, N. A. 2016. The impact of the Syrian Arc Orogeny on the Early Paleogene rocks, western shoulder of the Gulf of Suez, Egypt. Palaeogeography, Palaeoclimatology, Palaeoecology, 454, 30-53.

Ferry, S., Grosheny, D., Backert, N., Atrops, F. 2015. The base-of-slope carbonate breccia system of Céüse (Tithonian, SE France): Occurrence of progradational stratification in the head plug of coarse granular flow deposits. Sedimentary Geology, 317, 71-86.

Flügel, E. 2004. Microfacies of carbonate rocks. Springer, Berlin, 976 pp. 
Gawenda, P., Winkler, W., Schmitz, B., Adatte, T. 1999. Climate and bioproductivity control on carbonate turbidite sedimentation (Paleocene to earliest Eocene, Gulf of Biscay, Zumaia, Spain). Journal of Sedimentary Research, 69, 1253-1261.

Gawthorpe, R.L., Jackson, C.A.L., Young, M.J., Sharp, I.R., Moustafa, A.R. 2003. Normal fault growth, displacement localisation and the evolution of normal fault populations: the Hammam Faraun fault block, Suez rift, Egypt. Journal of Structural Geology, 25, 883-895.

George, A.D., Playford, P.E., Powell, C. McA. 1995. Platform-margin collapse during Famennian reef evolution, Canning Basin, Western Australia. Geology, 23, 691-694.

Grammer, G. M., Ginsburg, R. N. 1992. Highstand versus lowstand deposition on carbonate platform margins: insight from Quaternary foreslopes in the Bahamas. Marine Geology, 103, $125-136$.

Grammer, G. M., Harris, P. M., Eberli, G.P. 2004. Integration of outcrop and modern analogs in reservoir modeling: Overview with examples from the Bahamas, in Integration of outcrop and modern analogs in reservoir modeling. AAPG Memoir, 80, 1-22.

Grosheny, D., Ferry, S., Courjault, T. 2015. Progradational patterns at the head of single units of base-of-slope, submarine granular flow deposits (“Conglomérats des Gâs”, Coniacian, SE France). Sedimentary Geology, 317, 102-115. 
Grove, C., Jerram, D. 2011. jPOR: An ImageJ macro to quantify total optical porosity from bluestained thin sections. Computers and Geosciences, 37, 1850-1859.

Haak, A.B., Schlager, W. 1989. Compositional variations in calciturbidites due to sea-level fluctuations, late Quaternary, Bahamas. Geologische Rundschau, 78, 477-486.

Hairabian, A., Borgomano, J., Masse, J. P., Nardon, S. 2015. 3D stratigraphic architecture, sedimentary processes and controlling factors of Cretaceous deep-water resedimented carbonates (Gargano Peninsula, SE Italy). Sedimentary Geology, 317, 116-136.

Hammad, M.A. 1975. Geological Map of Egypt. Appendix 1. Soil Survey Papers no. 11.

Haq, B.U., Hardenbol, J., Vail, P.R. 1988. Mesozoic and Cenozoic chronostratigraphy and cycles of sea-level change. In: Sea-Level Changes - an Integrated Approach (Ed. C.K. Wilgus SEPM Special Publication, 42, 71-108.

Harris, M.T. 1994. The foreslope and toe-of-slope facies of the Middle Triassic Latemar buildup (Dolomites, Northern Italy). Journal of Sedimentary Research, B64, 132-145.

Haughton, P. Davis, C., McCaffrey, W., Barker, S. 2009. Hybrid sediment gravity flow deposits - Classification, origin and significance. Marine and Petroleum Geology, 26, 1900-1918. 
Hiscott, R.N., James, N.P. 1985. Carbonate debris flows, Cow Head Group, Western Newfoundland. Journal of Sedimentary Petrology, 55, 735-745.

Hobson, J. P., Caldwell, C. D., Toomey, D. F. 1985. Early Permian deep-water allochthonous limestone facies and reservoir, west Texas. AAPG Bulletin, 69, 2130-2147.

Hodson, J. M., Alexander, J. 2010. The effects of grain-density variation on turbidity currents and some implications for the deposition of carbonate turbidites. Journal of Sedimentary Research, 80, 515-528.

Homewood, P. W., Eberli, G. P. 2000. Genetic stratigraphy on the exploration and the production scales. Bulletin du Centre de Recherche Elf Exploration Production Memoire, 24, $1-290$.

Höntzsch, S., Scheibner, C., Kuss, J., Marzouk, A.M., Rasser, M.W. 2011a. Tectonically driven carbonate ramp evolution at the southern Tethyan shelf: the Lower Eocene succession of the Galala Mountains, Egypt. Facies, 57, 51-72.

Höntzsch, S., Scheibner, C., Guasti, E., Kuss, J., Marzouk, A. M., Rasser, M. W. 2011 b. Increasing restriction of the Egyptian shelf during the Early Eocene?-New insights from a southern Tethyan carbonate platform. Palaeogeography, Palaeoclimatology, Palaeoecology, 302, 349-366. 
Ielpi, A., Cornamusini, G. 2013. An outer ramp to basin plain transect: Interacting pelagic and calciturbidite deposition in the Eocene-Oligocene of the Tuscan Domain, Adria Microplate (Italy). Sedimentary Geology, 294, 83-104.

Jablonská, D., Di Celma, C. N., Tondi, E., Alsop, G. I. 2017. Internal architecture of masstransport deposits in basinal carbonates: A case study from southern Italy. Sedimentology, Accepted Author Manuscript. doi:10.1111/sed.12420

Jackson, C.A.L., Gawthorpe, R.L., Sharp, I.R. 2002. Growth and linkage of the East Tanka fault zone, Suez rift: structural style and syn-rift stratigraphic response. Journal of Geological Society London, 159, 175-187.

Janson, X., Kerans, C., Loucks, R., Marhx, M. A., Reyes, C., Murguia, F. 2011. Seismic architecture of a Lower Cretaceous platform-to-slope system, Santa Agueda and Poza Rica fields, Mexico. AAPG bulletin, 95, 105-146.

Jorry, S. J., Hasler, C. A., Davaud, E. 2006. Hydrodynamic behaviour of Nummulites: implications for depositional models. Facies, 52, 221-235.

Jorry, S. J., Droxler, A. W., Francis, J. M. 2010. Deepwater carbonate deposition in response to re-flooding of carbonate bank and atoll-tops at glacial terminations. Quaternary Science Reviews, 29, 2010-2026. 
Krause, F.F., Oldershaw, A.E. 1979. Submarine carbonate breccia beds: a depositional model for two layer sediment gravity flows from the Sekwi Formation (Lower Cambrian), Northwest Territories, Canada. Canadian Journal of Earth Sciences, 16, 189-199.

Kuss, J., Scheiber, C., Gietl, R. 2000. Carbonate platform to basin transition along an Upper Cretaceous to Lower Tertiary Syrian Arc uplift, Galala Plateaus. Eastern Desert of Egypt. GeoArabia, 5, 405-424.

Lowe, D.R. 1976. Grain-flow and grain-flow deposits. Journal of Sedimentary Petrology. 46, $188-199$.

Lowe, D. R. 1982. Sediment gravity flows: II Depositional models with special reference to the deposits of high-density turbidity currents. Journal of Sedimentary Research, 52, 279-297.

Lowe, D. R., Guy, M. 2000. Slurry - flow deposits in the Britannia Formation (Lower Cretaceous), North Sea: a new perspective on the turbidity current and debris flow problem. Sedimentology, 47, 31-70.

Martini, E. 1970. Standard Palaeogene calcareous nannoplankton zonation. Nature, 226, p. 560.

Martinsen, O.J. 1994. Mass movements. In: The Geological Deformation of Sediments (Ed. A. Maltman) Chapman \& Hall, pp. 127-165. 
McIlreath, I. A. 1977. Accumulation of a Middle Cambrian Deep Water Limestone Debris Apron Adjacent to a Vertical Submarine Carbonate Escarpment Southern Rocky Mountains Canada. SEPM Special Publication, 25, 113-124.

McIlreath, I.A., James, N.P. 1979. Facies models 12: Carbonate Slopes. In: Walker, R.G. (Ed.) Facies Models, Geoscience Canada, Geological Association Canada, 133-143.

Melim, L.A., Scholle, P.A. 1995. The forereef facies of the Permian Capitan Formation, The role of sediment supply versus sea-level changes. Journal of Sedimentary Research, 65, 107-118.

Miller, K.G., Kominz, M.A., Browning, J.V, Wright, J.D., Mountain, G.S., Katz, M.E., Sugarman, P.J., Cramer, B.S., Christie-Blick, N., Pekar, S.F. 2005. The Phanerozoic Record of Global Sea-Level Change. Science, 310, 1293-1298.

Moustafa, A.R., Abdeen, A.R. 1992. Structural setting of the Hammam Faraun fault block, eastern side of the Suez rift. Journal of University Kuwait (Science), 19, 291-310.

Moustafa, A.R., Khalil, M.H. 1995. Superposed deformation in the Northern Suez Rift, Egypt: Relevance to hydrocarbons exploration. Journal of Petroleum Geology, 18, 245-266.

Moustafa, A. R. 2013. Fold-related faults in the Syrian Arc belt of northern Egypt. Marine and Petroleum Geology, 48, 441-454. 
Moustafa, A.R. 2014. Structural architecture and tectonic evolution of the Maghara inverted basin, Northern Sinai, Egypt. Journal of Structural Geology, 62, 80-96.

Mulder, T., Cochonat, P. 1996. Classification of offshore mass movements. Journal of Sedimentary Research, 66, 43-57.

Mulder, T., Alexander, J. 2001. The physical character of subaqueous sedimentary density flows and their deposits. Sedimentology, 48, 269-299.

Mulder, T., Ducassou, E., Eberli, G.P., Hanquiez, V., Gonthier, E., Kindler, P., Principaud, M., Fournier, F., Léonide, P., Billeaud, I., Marsset, B. 2012. New insights into the morphology and sedimentary processes along the western slope of Great Bahama Bank. Geology, 40, 603606.

Mulder, T., Ducassou, E., Gillet, H., Hanquiez, V., Principaud, M., Chabaud, L., Eberli, G.P., Kindler, P., Billeaud, I., Gonthier, E., Fournier, F., Léonide, P., Borgomano, J. 2014. First Discovery of Channel-Levee Complexes In A Modern Deep-Water Carbonate Slope Environment. Journal of Sedimentary Research, 84, 1139-1146.

Mullins, H. T., Neumann, A. C. 1979. Deep carbonate bank margin structure and sedimentation in the northern Bahamas. In: Society of Economic Paleontology Mineralogists Special Publication, 27, 165-192. 
Mullins, H.T., Cook, H.E. 1986. Carbonate apron models: Alternatives to the submarine fan model for paleoenvironmental analysis and hydrocarbon exploration. Sedimentary Geology, $48,37-79$.

Mullins, H. T., Gardulski, A. F., Mine, A. C. 1986. Catastrophic collapse of the west Florida carbonate platform margin. Geology, 14, 167-170.

Payros, A., Pujalte, V. 2008. Calciclastic submarine fans: An integrated overview. Earth-Science Reviews, 86, 203-246.

Patton, T.L., Moustafa, A.R., Nelson, R.A., Abdine, S.A. 1994. Tectonic evolution and structural setting of the Suez rift. In: Landon, S.M. (Ed.) Interior Rift Basin. American Association of Petroleum Geologists Memoir, 59, pp. 9-55.

Pickering, K.T., Corregidor, J. 2005. Mass-transport complexes (MTCs) and tectonic control on basin-floor submarine fans, Middle Miocene, south Spanish Pyrenees. Journal of Sedimentary Research, 75, 761-783.

Piper, D. J., Cochonat, P., Morrison, M. L. 1999. The sequence of events around the epicentre of the 1929 Grand Banks earthquake: initiation of debris flows and turbidity current inferred from sidescan sonar. Sedimentology, 46, 79-97. 
Playton, T., Janson, X., Kerans, C. 2010. Carbonate slopes, in James, N.P., and Dalrymple, R.W., eds. Facies models 4: St. John's, Newfoundland, Geological Association of Canada, 449-476.

Playton, T. E., Kerans, C. 2015. Late Devonian Carbonate Margins and Foreslopes of the Lennard Shelf, Canning Basin, Western Australia, Part B: Development During Progradation and Across the Frasnian-Famennian Biotic Crisis. Journal of Sedimentary Research, 85, $1362-1392$.

Postma, G. 1986. Classification for sediment gravity-flow deposits based on flow conditions during sedimentation. Geology, 14, 291-294.

Pratson, L. F., Imran, J., Parker, G., Syvitski, J. P., Hutton, E. 2000. AAPG Memoir 72/SEPM Special Publication No. 68, Chapter 6: Debris Flows vs. Turbidity Currents: a Modeling Comparison of Their Dynamics and Deposits, 52-72.

Principaud, M., Mulder, T., Gillet, H., Borgomano, J. 2015. Large-scale carbonate submarine mass-wasting along the northwestern slope of the Great Bahama Bank (Bahamas): morphology, architecture, and mechanisms. Sedimentary Geology, 317, 27-42.

Puga-Bernabéu, Á, Webster, J.M., Beaman, R.J., Reijmer, P.J., Renema, W. 2014. Filling the gap: A 60 ky record of mixed carbonate-siliciclastic turbidite deposition from the Great Barrier Reef. Marine and Petroleum Geology, 50, 40-50. 
Rasser, M. W., Scheibner, C., Mutti, M. 2005. A paleoenvironmental standard section for Early Ilerdian tropical carbonate factories (Corbieres, France; Pyrenees, Spain). Facies, 51, 218232.

Reijmer, J.J.G., Ten Kate, W.G.H.Z., Sprenger, A., Schlager, W. 1991. Calciturbidite composition related to exposure and flooding of a carbonate platform (Triassic, Eastern Alps). Sedimentology, 38, 1059-1074.

Reijmer, J. J. G. 1998. Compositional variations during phases of progradation and retrogradation of a Triassic carbonate platform (Picco di Vallandro/Dürrenstein, Dolomites, Italy). International Journal of Earth Sciences. Geologische Rundschau, 87, 436-448.

Reijmer, J. J.G., Palmieri, P., Groen, R. 2012. Compositional variations in calciturbidites and calcidebrites in response to sea-level fluctuations (Exuma Sound, Bahamas). Facies, 58, 493507.

Reijmer, J.J.G., Mulder, T., Borgomano, J. 2015a. Carbonates and gravity deposits. Sedimentary Geology, 317, 1-8.

Reijmer, J. J., Palmieri, P., Groen, R., Floquet, M. 2015b. Calciturbidites and calcidebrites: Sealevel variations or tectonic processes? Sedimentary Geology, 317, 53-70. 
Salem, A.M.K., Abdel-Wahab, A.A., McBride, E.F. 1998. Diagenesis of shallowly buried cratonic sandstones, southwest Sinai, Egypt. Sedimentary Geology, 119, 311-335.

Savary, B., Ferry, S. 2004. Geometry and petrophysical parameters of a calcarenitic turbidite lobe (Barremian-Aptian, Pas-de-la-Cluse, France). Sedimentary Geology, 168, 281-304.

Shanmugam, G., 1996. High-density turbidity currents: are they sandy debris flows? Perspectives. Journal of sedimentary Research, 66, 2-10.

Scheibner, C., Kuss, J., Marzouk, A.M. 2000. Slope sediments of a Paleocene ramp-to-basin transition in NE Egypt. International Journal of Earth Sciences, 88, 708-724.

Scheibner, C., Marzouk, A. M., Kuss, J. 2001. Maastrichtian-Early Eocene litho-biostratigraphy and palægeography of the northern Gulf of Suez region, Egypt. Journal of African Earth Sciences, 32, 223-255.

Scheibner, C., Reijmer, J.J.G., Marzouk, A.M., Speijer, R.P., Kuss, J. 2003. From platform to basin: the evolution of a Paleocene carbonate margin (Eastern Desert, Egypt). International Journal of Earth Science, 92, 624-640.

Scheibner, C., Speijer, R.P., Marzouk, A.M. 2005. Turnover of larger foraminifera during the Paleocene-Eocene Thermal Maximum and paleoclimatic control on the evolution of platform ecosystem. Geology, 33, 493-496. 
Scheibner, C., Speijer, R.P. 2008. Late Paleocene-early Eocene Tethyan carbonate platform evolution - A response tolong- and short-term paleoclimatic change. Earth-Science Reviews, 90, 71-102.

Scheibner, C., Speijer, R. P. 2009. Recalibration of the Tethyan shallow-benthic zonation across the Paleocene-Eocene boundary: the Egyptian record. Geologica Acta: An International Earth Science Journal, 7, 195-214.

Schlager, W., Ginsburg, R. N. 1981. Bahama carbonate platforms- the deep and the past. Marine Geology, 44, 1-24.

Serra-Kiel, J., Hottinger, L., Caus, E., Drobne, K, Ferrandez, C, Jauhri, A.K., Less, G., Pavlovec, R., Pignatti, J., Samso, J.M., Schaub, H. 1998. Larger foraminiferal biostratigraphy of the Tethyan Paleocene and Eocene. Bulletin de la Société géologique de France, 169, 281-99.

Sharp, I.R., Gawthorpe, R.L., Armstrong, B., Underhill, J.R. 2000. Propagation history and passive rotation of mesoscale normal faults: implications for syn-rift stratigraphic development. Basin Research, 12, 285-306.

Sharp, I., Gillespie, P., Morsalnezhad, D., Taberner, C., Karpuz, R., Vergés, J., Horbury, A., Pickard, N., Garland, J., Hunt, D. 2010. Stratigraphic architecture and fracture-controlled dolomitization of the Cretaceous Khami and Bangestan groups: an outcrop case study, Zagros 
Mountains, Iran. In: Mesozoic and Cenozoic Carbonate Systems of the Mediterranean and the Middle East: Stratigraphic and Diagenetic Reference Models (Eds F.S. Van Buchem, K.D.

Gerdes, and M. Esteban). Geological Society of London Special Publication, 329, p. 343-396.

Sola, F., Puga-Bernabéu, Á., Aguirre, J., Braga, J. C. 2017. Heterozoan carbonate deposition on a steep basement escarpment (Late Miocene, Almería, south-east Spain). Sedimentology, 64, $1107-1131$.

Spence, G. H., Tucker, M. E. 1997. Genesis of limestone megabreccias and their significance in carbonate sequence stratigraphic models: a review. Sedimentary Geology, 112, 163-193.

Spence G. H., Finch E. 2014. Influences of nodular chert rhythmites on natural fracture networks in carbonates: an outcrop and two-dimensional discrete element modelling study. In: Advances in the Study of Fractured Reservoirs (Eds G.H. Spence, J. Redfern, R. Aguilera, T.G. Bevan, J.W. Cosgrove, G.D. Couples, and J. Daniel). Geological Society of London Special Publication, 374, 211-249.

Talling, P. J., Masson, D. G., Sumner, E. J., Malgesini, G. 2012. Subaqueous sediment density flows: depositional processes and deposit types. Sedimentology. 59, 1937-2003.

Watts, K. F., Garrison, R. E. 1986. Sumeini Group, Oman-Evolution of a mesozoic carbonate slope on a south Tethyan continental margin. Sedimentary Geology, 48, 107-168. 
Whidden, K. J., Jones, R. W. 2012. Correlation of early Paleogene global diversity patterns of large benthic foraminifera with Paleocene and Eocene climatic events. PALAIOS, 27, 235251.

Wilson, P., Gawthorpe, R. L., Hodgetts, D., Rarity, F., Sharp, I. R. 2009. Geometry and architecture of faults in a syn-rift normal fault array: the Nukhul half-graben, Suez rift, Egypt. Journal of Structural Geology, 31, 759-775.

Wilson, M.E.J., Chambers, J.L.C., Manning, C., Nas, D.S. 2012. Spatio-temporal evolution of a Tertiary carbonate platform margin and adjacent basinal deposits. Sedimentary Geology, 271, $1-27$.

Wilson, M. E. 2015. Oligo-Miocene variability in carbonate producers and platforms of the Coral Triangle biodiversity hotspot: habitat mosaics and marine biodiversity. Palaios, 30, $150-168$.

Wunsch, M., Betzler, C., Lindhorst, S., Lüdmann, T., Eberli, G. P. 2017. Sedimentary dynamics along carbonate slopes (Bahamas archipelago). Sedimentology, 64, 631-657.

Yilmaz, C. 2006. Platform-slope transition during rifting: The mid-Cretaceous succession of the Amasya Region (Northern Anatolia), Turkey. Journal of Asian Earth Sciences, 27, 194-206. 
Young, M.J., Gawthorpe, R.L., Sharp, I.R. 2003. Normal fault growth and early syn-rift sedimentology and sequence stratigraphy: Thal Fault, Suez Rift, Egypt. Basin Research, 15, $479-502$.

Yose, L.A., Heller, P.L. 1989. Sea-level control of mixed-carbonate-siliciclastic, gravity-flow deposition: Lower part of the Keeler Canyon Formation (Pennsylvanian), southeastern California. Geological Society of America Bulletin, 101, 427-439.

Youssef, M.M. 2003. Structural setting of central and south Egypt: An overview. Micropaleontology, 49, 1-13. 
Figure 1 - Hammam Faraun study area. A) Regional map showing the locations of the stable and unstable platform, Syrian Arc Fold Belt compressional features, and locations of other Thebes Formation studies (modified from Bosworth et al., 1999).

B) Map of the Hammam Faraun fault block showing the distribution of major facies (modified from Moustafa and Abdeen, 1992 and Sharp et al., 2000). 
Figure 2 - Regional stratigraphy in the Hammam Faraun fault block study area (left; Young et al., 2003; Wilson et al., 2009). A generalized stratigraphic column showing the distribution of facies in the Thebes Formation in the HFFB (right). The legend provided describes symbols used in this figure and Figure 4. 
Figure 3 - Measurement of remobilized facies using image analysis. A) An example of a photo collage with debris flow facies (R-1) digitized for image analysis. B) Facies R-5 digitized from satellite imagery. These geobodies were identified and traversed in Wadi Wasit (Fig. 1B) to confirm their continuity. (C) A crossplot showing the horizontal distance, along depositional dip versus thickness of the R-1 geobodies. These measurements were calibrated with a laser range finder in the field. (D) A crossplot showing the difference in the lateral extent of facies R-1 and R-5, which were the most common facies in the lower and upper Thebes Formation in the HFF block, respectively. 
Figure 4 - Cross-section through the hanging wall of the Gebel Fault in the Hammam Faraun fault block showing the vertical distribution and morphology of the remobilized geobodies. Legend for the stratigraphic logs is in Figure 2. The "breccia" shown in log 82 in this figure is not described in the text. This is a minor unit in the overall succession and is a result of structural alteration accompanying movement along the Wadi Araba fault. 
Figure 5 - In situ foraminifera packstones to grainstones (Slope packstone facies S-1). A) and B) slope packstone beds with intercalated recessive unconsolidated grainstone beds. C) Neomorphosed slope packstones with floating planktonic foraminifera (Pl). D) Slope packstone comprised of Nummulites (N), echinoids (E), and quartz grains (Qz). 
Figure 6 - Planktonic foraminiferal wackestone (Basinal wackestones facies B-1). A) White planktonic wackestone cliffs ( $>30 \mathrm{~m}$; white) on top of the Hammam Faraun fault block. B) Planktonic foraminifera wackestone showing faint laminations. C) Photomicrograph of basinal wackestone facies showing alignment of planktonic foraminifera $(\mathrm{P})$. 
Figure 7 - Matrix-supported conglomerate - Debris flow facies R-1. A) Matrix-supported conglomerates in a background of slope packstones in a WNW-ESE oriented cliff section at Hammam Faraun, highlighted in B. C) Dolomitized facies R-1 shows clast molds. All of the clasts in this occurrence were dissolved out. The contrast between the mold and matrix illustrates the matrix to clast ratio in facies R-1. D) Photomicrograph of clast $(\mathrm{Cl})$ and matrix $(\mathrm{Mx})$. Allochems in visible in clast - green alga $(\mathrm{G})$ and Nummulites $(\mathrm{N})$ and in matrix - Nummulites (N), Alveolina (A) and quartz grains (Qz). E) Facies R-1 (dashed black outline) surrounded by autochthonous facies S-1. 
Figure 8 - Graded foraminiferal pack- to grainstone (Turbidite pack- to grainstone facies R-2). A) Grading in Lower Thebes Formation R-2 facies - note clast molds at the base fining up to fine-grained foraminiferal pack- to grainstone. B), C), and D) close-ups showing change in allochem size in foraminiferal grainstones (shown graded in A). E) Photomicrograph of coarsegrained foraminifera grainstone (shown in D) containing Alveolina (Al), Nummulites (N), and Echinoid fragment (Ec), with floating dolomite rhombs. F) Photomicrograph of medium-grained foraminifera (shown in C) grainstone containing Nummulites $(\mathrm{N})$, echinoids (Ec), and Discocyclina (Ds). Samples E and F are partially dolomitized.

Figure 9 - Clast-supported conglomerate (Facies R-3) A) Field photo of the clast-supported debris sheet unit in the Lower Thebes Formation (black arrows). B) Debris sheet facies overlying 
recessive slope packstone facies (S-1). C) Photomicrograph of clast in the clast-supported conglomerate, with shallow-water dasycladean alga (Ds), red alga (Rd), and Mi (Miliolida) in the clast. 
Figure 10 - Dasyclad foraminiferal grainstone (Slumped grainstone facies R-4). A) Slumped grainstone beds (arrows) in a Wadi wall at Hammam Faraun. B) Neomorphosed foraminifera grainstone with molds of Alveolina (A), Nummulites (N), dasyclad alga (Ds), unidentified benthic foraminifera, and echinoid fragments (Ec). C) Neomorphosed dasycladean alga (Ds) grainstone from a slumped bed in the upper part of the Lower Thebes Formation with two floating Alveolina (A). 
Figure 11 - Foraminiferal grainstone (High-density turbidite grainstone facies R-5). A) Highdensity turbidite facies $(\mathrm{G})$ in a background of planktonic foraminifera wackestone $(\mathrm{W})$ in Wadi Wasit, Hammam Faraun. B) Field photo showing a foraminiferal grainstone (G) intercalated with facies B-1 (W). Grainstone beds show displacement as a result of syndepositional faulting. C) Photomicrograph showing foraminiferal grainstone with glauconite grains (Gl), Alveolina (A) and Nummulites (N). D) Neomorphosed grainstone with upper to mid-ramp allochems, Alveolina (A), dasycladean alga (Ds), and green alga (Gr). 
Figure 12 - Dasyclad Miliolida grainstone (Channelized grainstone facies R-6). A) Channel grainstone facies (R-6) in basinal wackestone facies (B-1). Note accretionary surfaces in channel lens. B) Photomicrograph of channelized grainstone facies with dasycladean alga (Ds),

Nummulites (N), and echinoids (E). C) Neomorphosed dasycladean Miliolida grainstone floating Miliolida (M). 
Figure 13 - Regional map of structures associated with the SAFB and the HFFB study area in relation to studies of the Thebes Formation. 
Figure 14 - Geological map of the North and South Galala Plateaus in Egypt (modified from Hammad, 1975) with a cross section through the Wadi Araba fault, showing the inversion fault and resulting anticlinal ridge ( $c f$. Moustafa, 2014). These types of structures are found throughout Northern Egypt and Sinai. 


\section{Table 1}

Characteristics of remobilized carbonate facies. *Italic font denotes method used for measurement of remobilized facies in the field: Direct - directly at the exposure, Laser -using the laser range finder, and Image J - digitized photos and ImageJ software.

\begin{tabular}{|c|c|c|c|c|}
\hline Facies code & $\begin{array}{l}\text { Geobody } \\
\text { shape and } \\
\text { contacts } \\
\end{array}$ & $\begin{array}{l}\text { Dimensions and method } \\
\text { used for measurement* }\end{array}$ & $\begin{array}{l}\text { Sorting and } \\
\text { allochem/clast } \\
\text { size }\end{array}$ & retation \\
\hline $\begin{array}{l}\text { R-1: Matrix- } \\
\text { supported } \\
\text { conglomerate }\end{array}$ & $\begin{array}{l}\text { Lens-shaped; } \\
\text { irregular } \\
\text { basal } \\
\text { contact, } \\
\text { concave } \\
\text { upper } \\
\text { contact }\end{array}$ & $\begin{array}{l}\text { Down-dip length: 3-267 } \\
\mathrm{m} \\
\text { Along-strike length: } 2-64 \\
\mathrm{~m} \\
\text { Thickness: } 0.3-20 \mathrm{~m} \\
\text { Direct, Laser, ImageJ }\end{array}$ & $\begin{array}{l}\text { Poorly sorted } \\
\text { clasts; clast size } \\
1-50 \mathrm{~cm}\end{array}$ & $\begin{array}{l}\text { Viscous debris flow; } \\
\text { Drzewiecki and Simo, } \\
\text { 2002; Flügel, 2004; } \\
\text { Crevello and Schlager, } \\
\text { 1980; Yose and Heller, } \\
1989\end{array}$ \\
\hline $\begin{array}{l}\text { R-2: Graded } \\
\text { foraminiferal } \\
\text { grainstone }\end{array}$ & $\begin{array}{l}\text { Sheet-like: } \\
\text { sharp } \\
\text { irregular } \\
\text { basal } \\
\text { contact, flat } \\
\text { upper } \\
\text { contact }\end{array}$ & $\begin{array}{l}\text { Down-dip length: } 2-50 \mathrm{~m} \\
\text { Along-strike length: up to } \\
100 \mathrm{~m} \\
\text { Thickness: } 0.5-6 \mathrm{~m} \\
\text { Direct }\end{array}$ & $\begin{array}{l}\text { Sorted and/or } \\
\text { normal grading; } \\
\text { allochems are } \\
1.5-3 \mathrm{~cm} \text { at base } \\
\text { to } 0.1-0.5 \mathrm{~cm} \text { at } \\
\text { top }\end{array}$ & $\begin{array}{l}\text { Turbidite flow; Krause and } \\
\text { Oldershaw, 1979; Bosellini } \\
\text { et al., 1993; Drzewiecki } \\
\text { and Simo, 2002; Savary } \\
\text { and Ferry, 2004; Courjault } \\
\text { et al., 2011; Puga- } \\
\text { Bernabeu et al., 2014 }\end{array}$ \\
\hline $\begin{array}{l}\text { R-3: Clast- } \\
\text { supported } \\
\text { conglomerate }\end{array}$ & $\begin{array}{l}\text { Sheet-like: } \\
\text { scoured } \\
\text { base, sharp } \\
\text { flat upper } \\
\text { contact }\end{array}$ & $\begin{array}{l}\text { Down-dip length: up to } \\
1000 \mathrm{~m} \text {, Along-strike } \\
\text { length: up to } 1500 \mathrm{~m} \\
\text { Thickness: } 0.3-2 \mathrm{~m} \\
\text { Direct, Laser }\end{array}$ & $\begin{array}{l}\text { Moderate } \\
\text { sorting clasts; } \\
\text { clast size 5-40 } \\
\mathrm{cm}\end{array}$ & $\begin{array}{l}\text { Collapse debris sheet flow: } \\
\text { Cook et al., 1972, 1983; } \\
\text { Crevello and Schlager, } \\
\text { 1980; Mullins and Cook, } \\
\text { 1986; Yose and Heller, } \\
\text { 1989; Dzrewiecki and } \\
\text { Simo, 2002 }\end{array}$ \\
\hline $\begin{array}{l}\text { R-4: } \\
\text { Dasycladean } \\
\text { foraminiferal } \\
\text { grainstone }\end{array}$ & $\begin{array}{l}\text { Lens-shaped } \\
\text { bodies; sharp } \\
\text { upper and } \\
\text { lower } \\
\text { convex } \\
\text { contact } \\
\end{array}$ & $\begin{array}{l}\text { Down-dip length: } 1-5 \mathrm{~m} \text {, } \\
\text { Along-strike length: up to } \\
10 \mathrm{~m} \\
\text { Thickness: } 1-3 \mathrm{~m} \\
\text { Direct, Image } J\end{array}$ & $\begin{array}{l}\text { Poorly sorted; } \\
\text { allochems range } \\
\text { in size from } 0.1- \\
1 \mathrm{~mm}\end{array}$ & $\begin{array}{l}\text { Plastic flow slump; } \\
\text { Martinsen, 1994; } \\
\text { Dzrewiecki and Simo, } \\
\text { 2002; Eberli, 1987; } \\
\text { Crevello and Schlager, } \\
1980\end{array}$ \\
\hline $\begin{array}{l}\text { R-5: } \\
\text { Foraminiferal } \\
\text { grainstone }\end{array}$ & $\begin{array}{l}\text { Sheet-like; } \\
\text { sharp, flat } \\
\text { upper and } \\
\text { lower } \\
\text { contact }\end{array}$ & $\begin{array}{l}\text { Down-dip length and } \\
\text { along-strike length: } \\
\text { between } 57-940 \mathrm{~m} \\
\text { Thickness: } 0.5-10 \mathrm{~m} \\
\text { Direct, ImageJ }\end{array}$ & $\begin{array}{l}\text { Massive, } \\
\text { unsorted; } \\
\text { allochems range } \\
\text { in size from } \\
<0.1-2 \mathrm{~mm}\end{array}$ & $\begin{array}{l}\text { High density turbidite } \\
\text { flow; Haughton et al., } \\
\text { 2009; Dziewicki and Simo, } \\
\text { 2002; Crevello and } \\
\text { Schlager, 1980; Colacicchi } \\
\text { and Baldanza, 1986 }\end{array}$ \\
\hline
\end{tabular}




\begin{tabular}{|c|c|c|c|c|}
\hline $\begin{array}{l}\text { R-6: } \\
\text { Dasycladean } \\
\text { Miliolid } \\
\text { grainstone }\end{array}$ & $\begin{array}{l}\text { Lens-shaped; } \\
\text { scoured } \\
\text { base, convex } \\
\text { upper } \\
\text { contact }\end{array}$ & $\begin{array}{l}\text { Down-dip length: } \\
\text { unknown } \\
\text { Along-strike: } 3-5 \mathrm{~m} \\
\text { Thickness: } 8-20 \mathrm{~m} \\
\text { Direct, Laser, ImageJ }\end{array}$ & $\begin{array}{l}\text { Unsorted to } \\
\text { moderately } \\
\text { sorted; } \\
\text { allochems range } \\
\text { in size from } \\
<0.1-1 \mathrm{~mm}\end{array}$ & $\begin{array}{l}\text { Channelized flow; Payros } \\
\text { and Pujalte, } 2008\end{array}$ \\
\hline
\end{tabular}



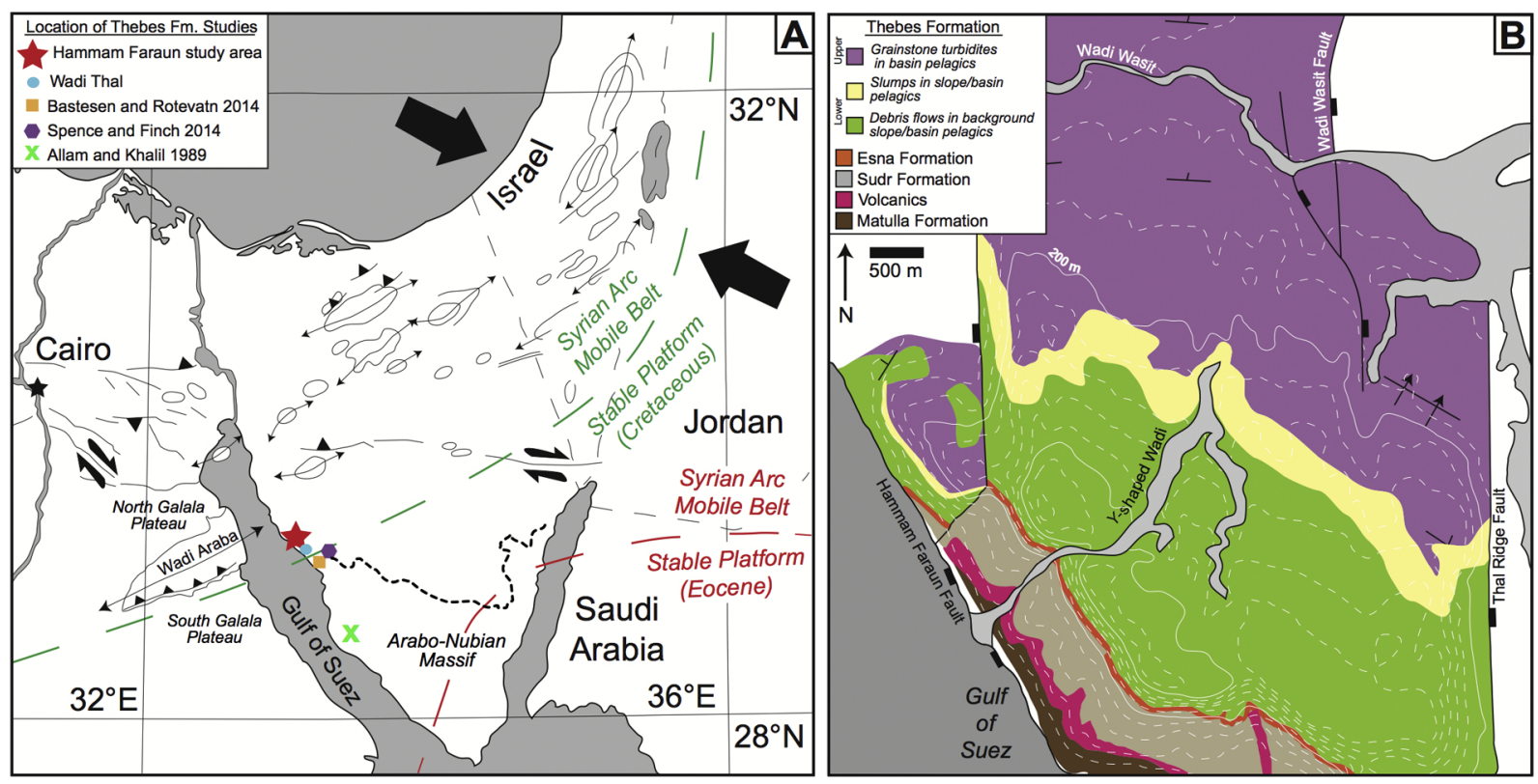

Figure 1 


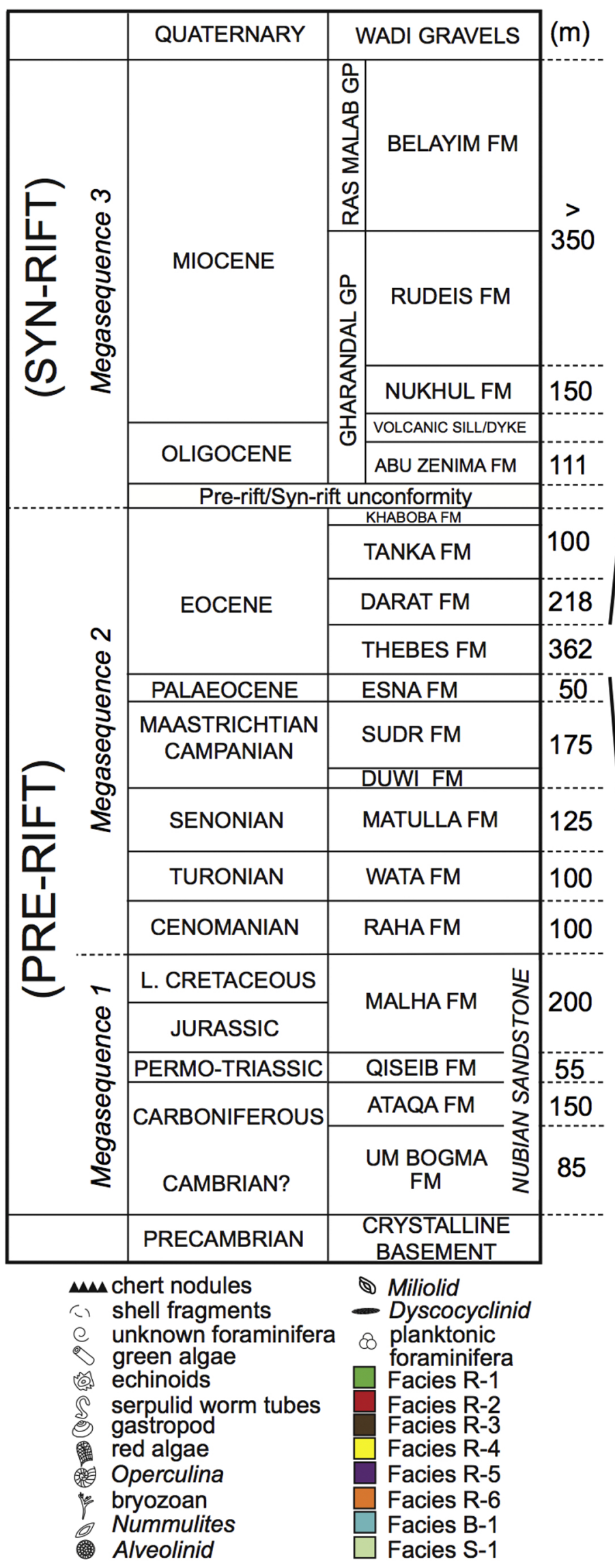

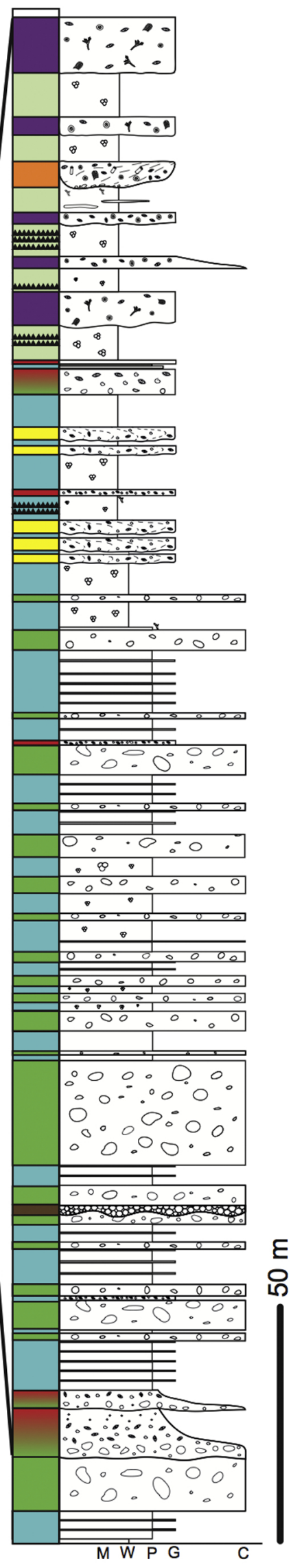



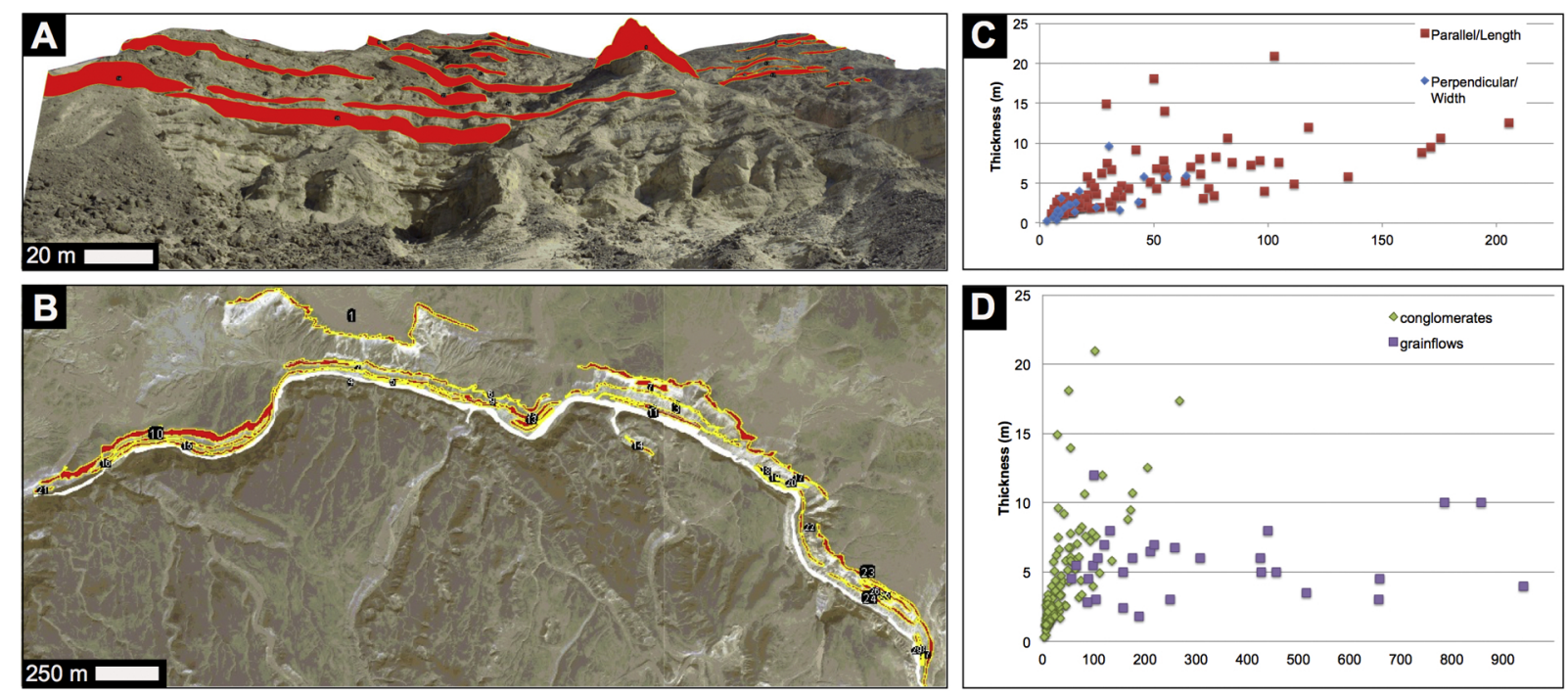

Figure 3 


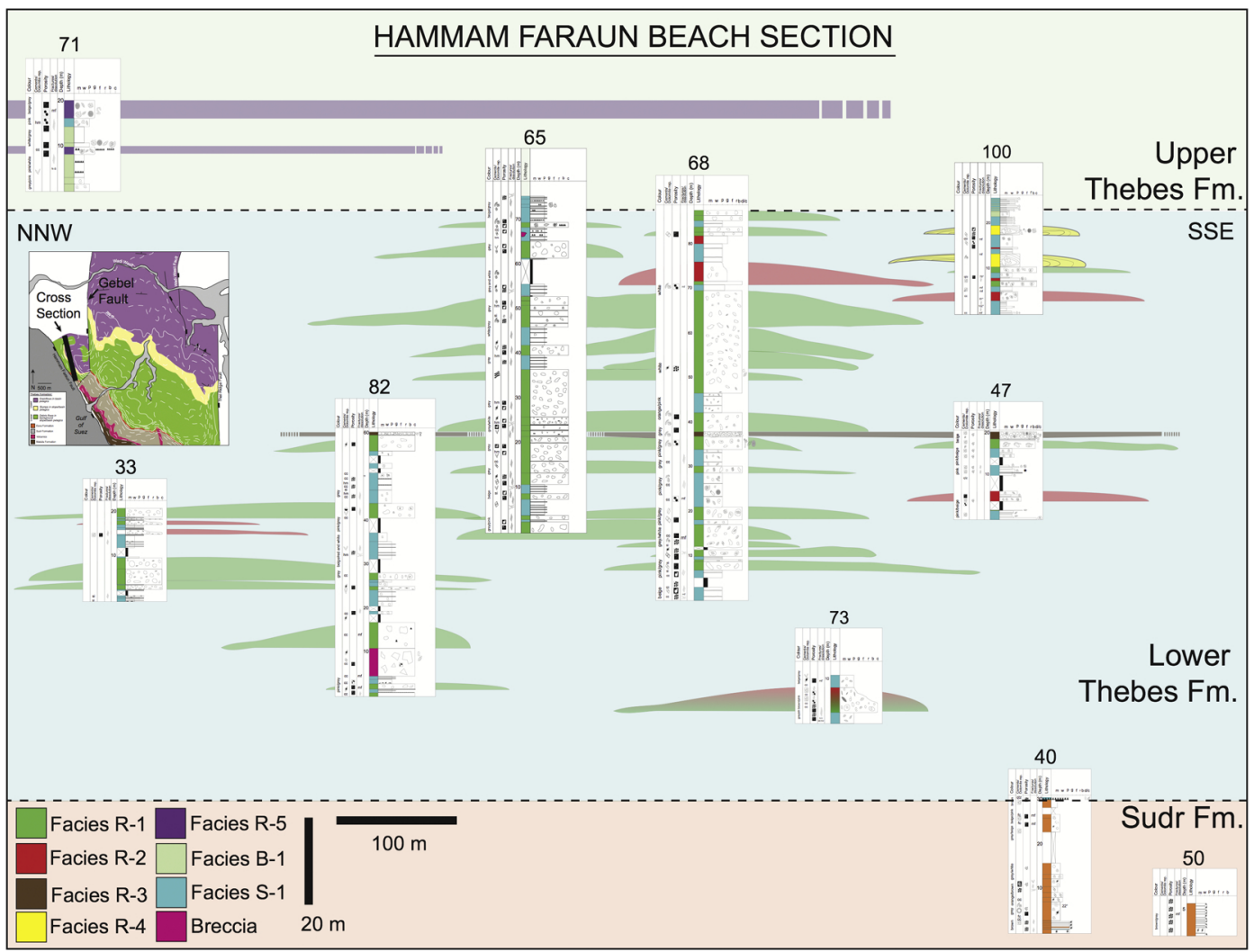

Figure 4 

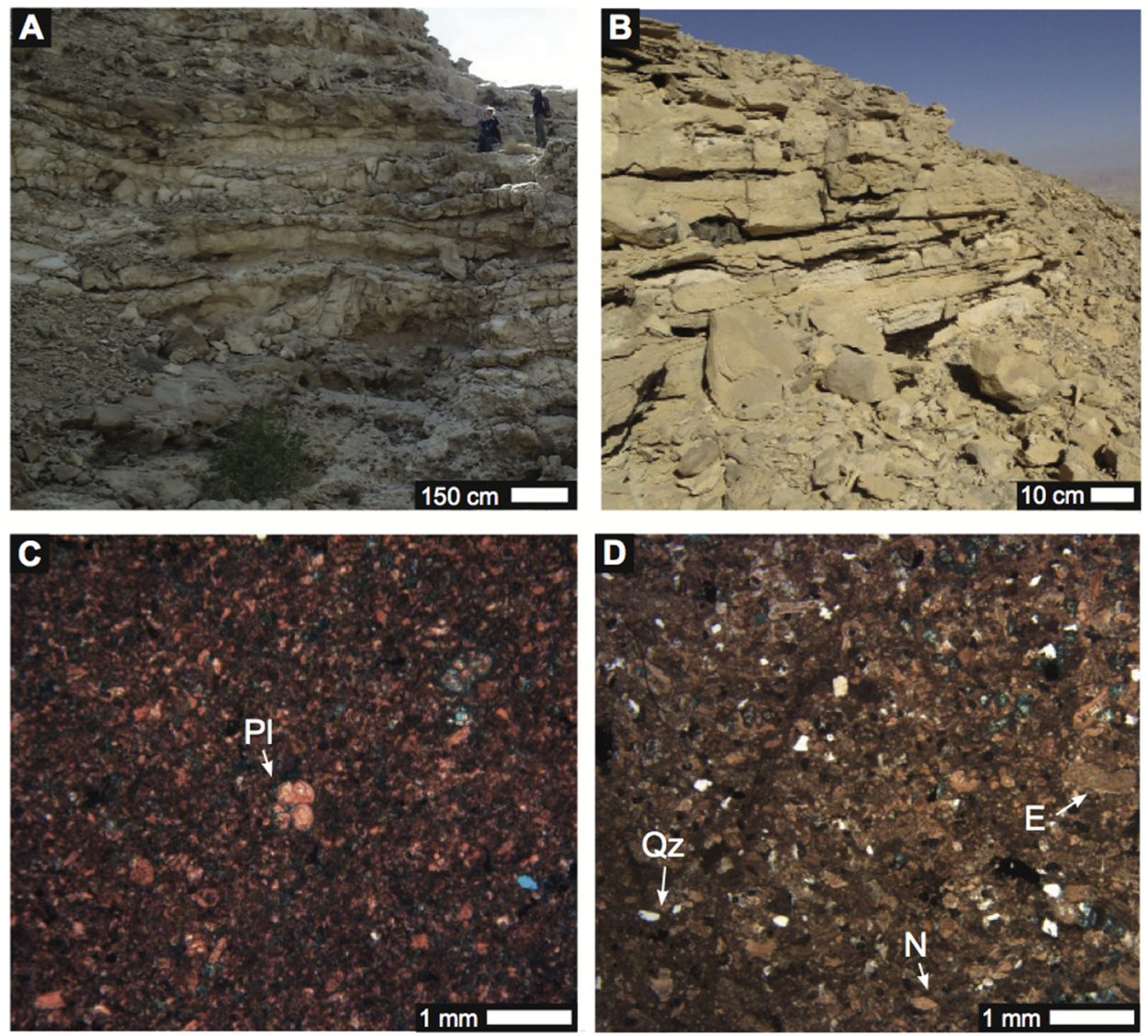

Figure 5 


\section{A}

$x=m-\frac{1}{10}$

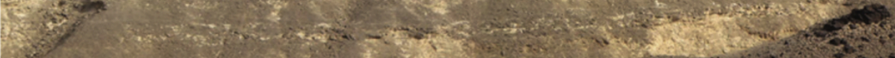

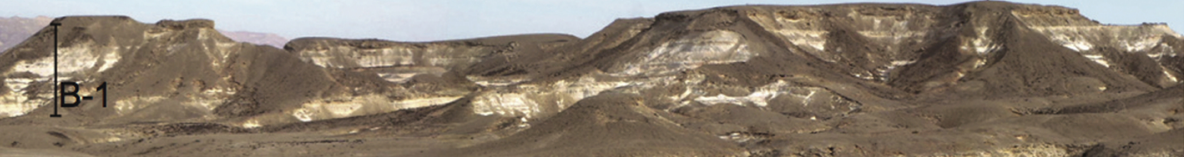

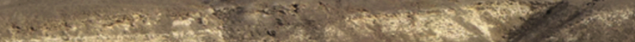

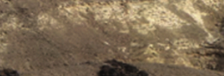
yon:

$15 \mathrm{~m}$
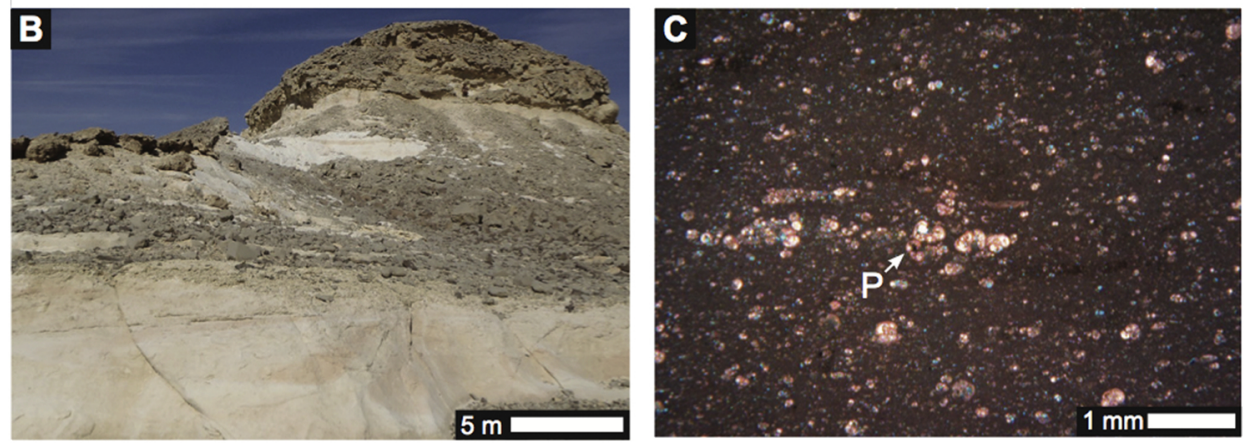

Figure 6 

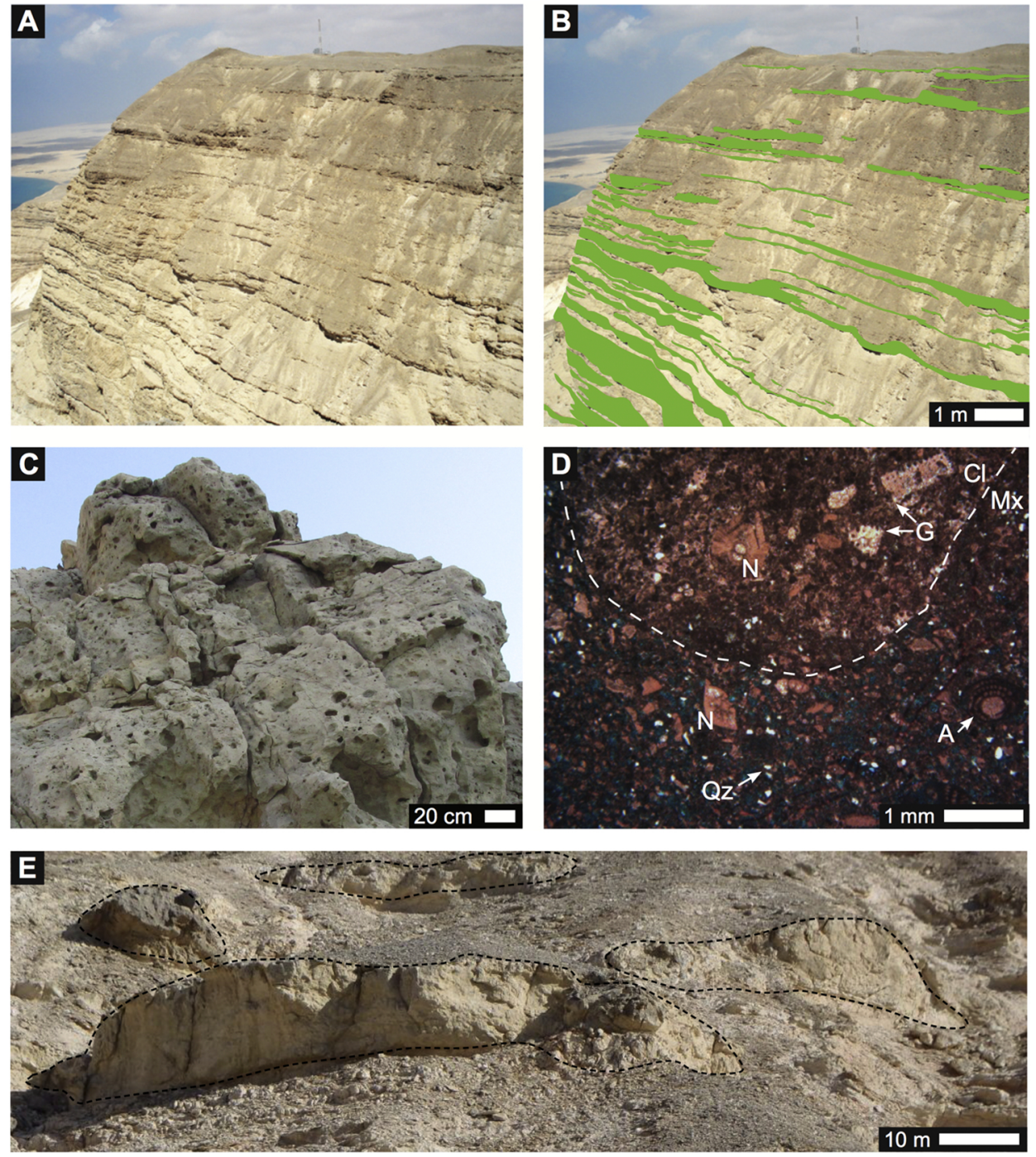

Figure 7 


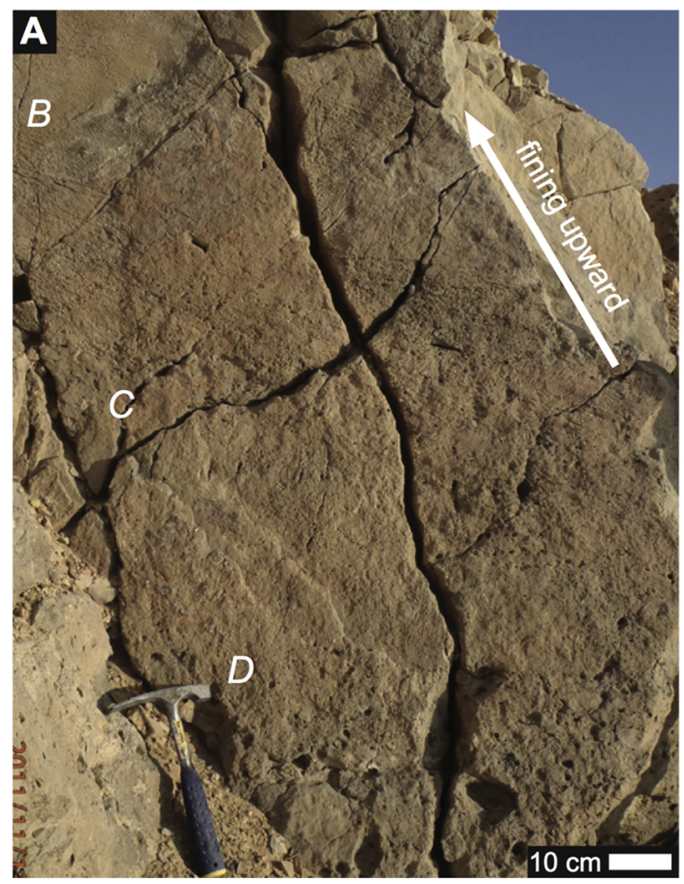

B

$10 \mathrm{~cm}$
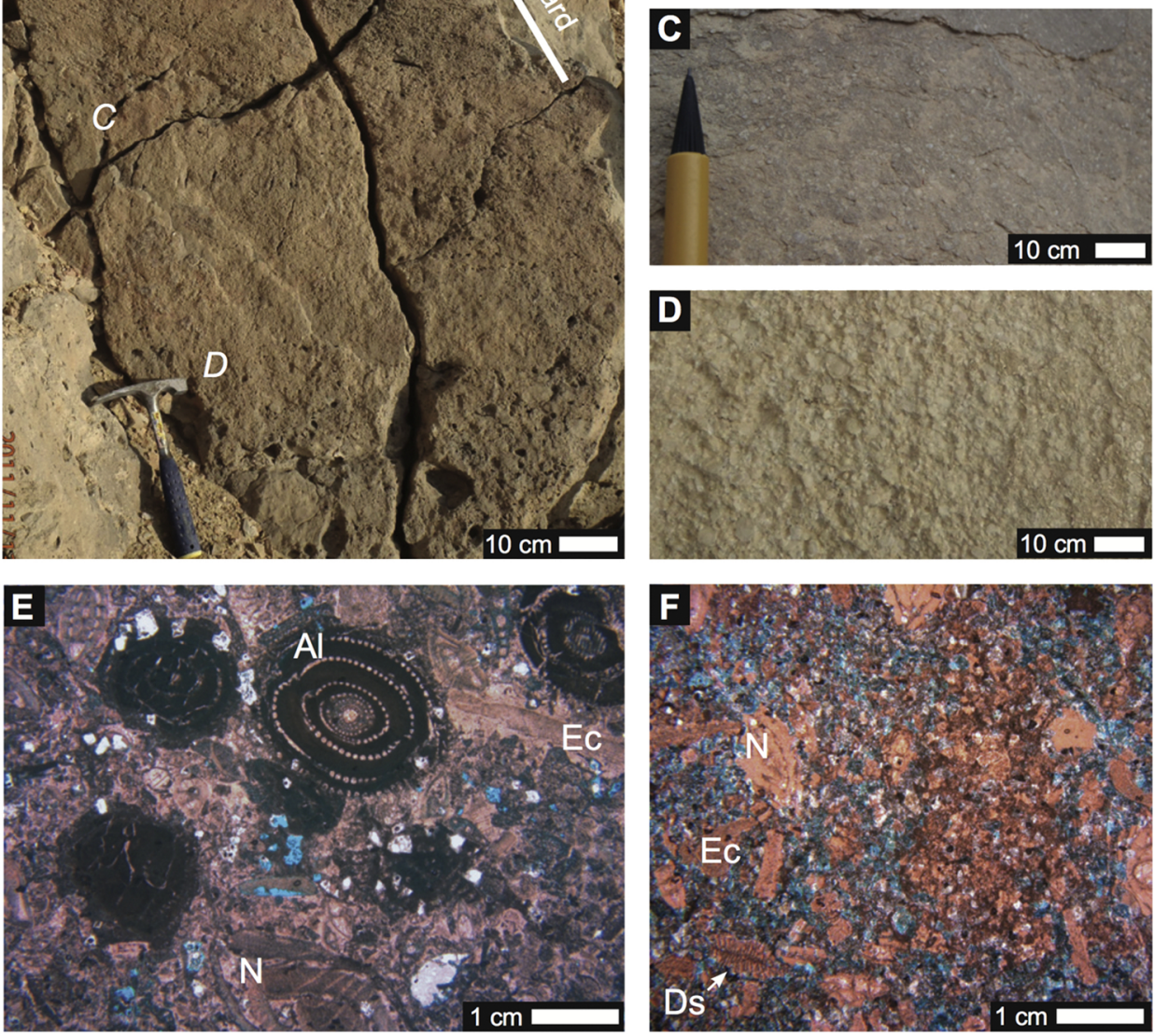

Figure 8 


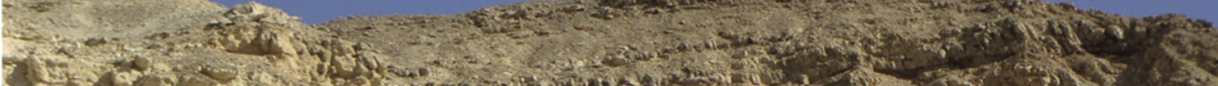

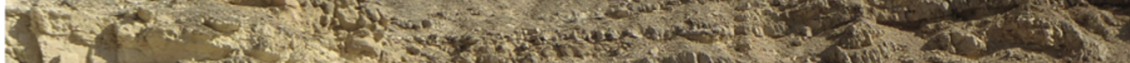

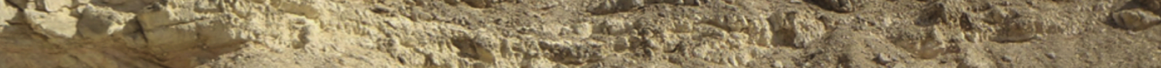
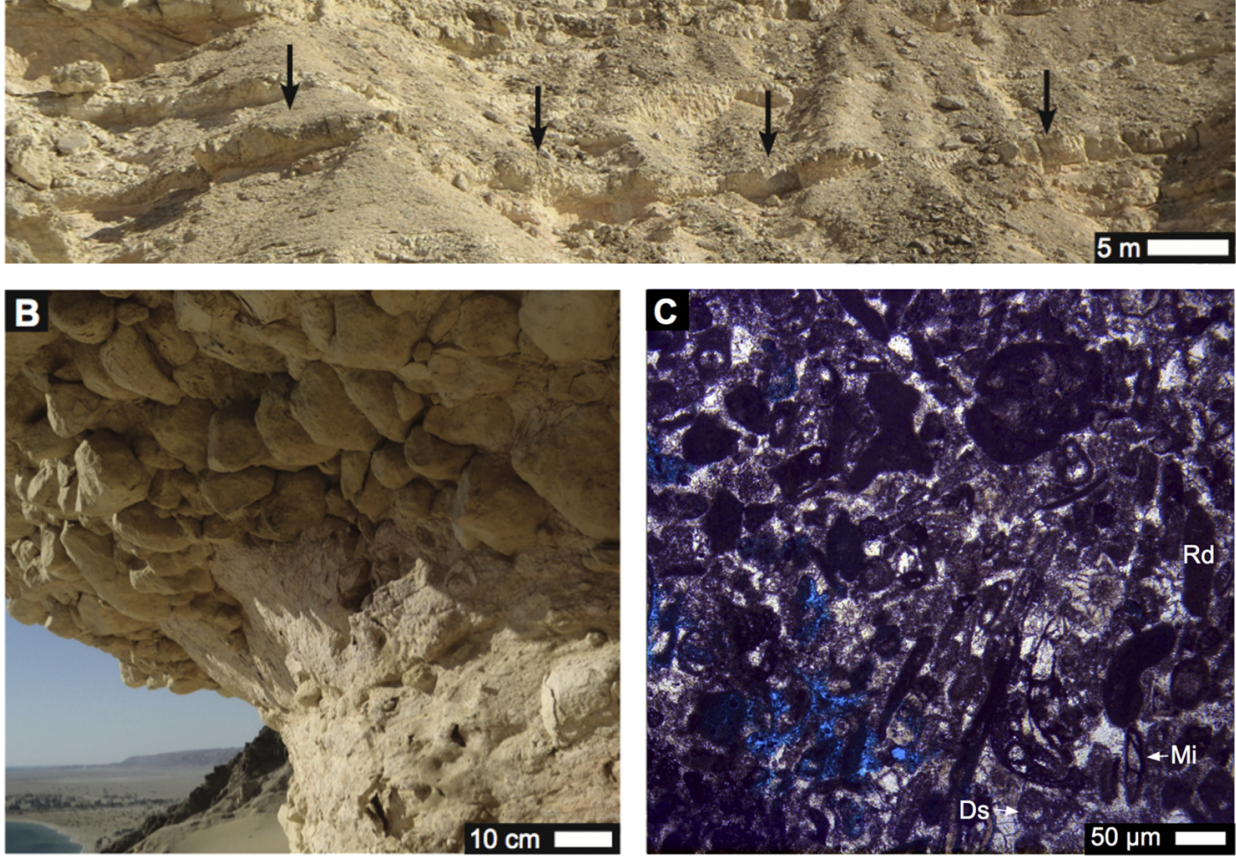

Figure 9 

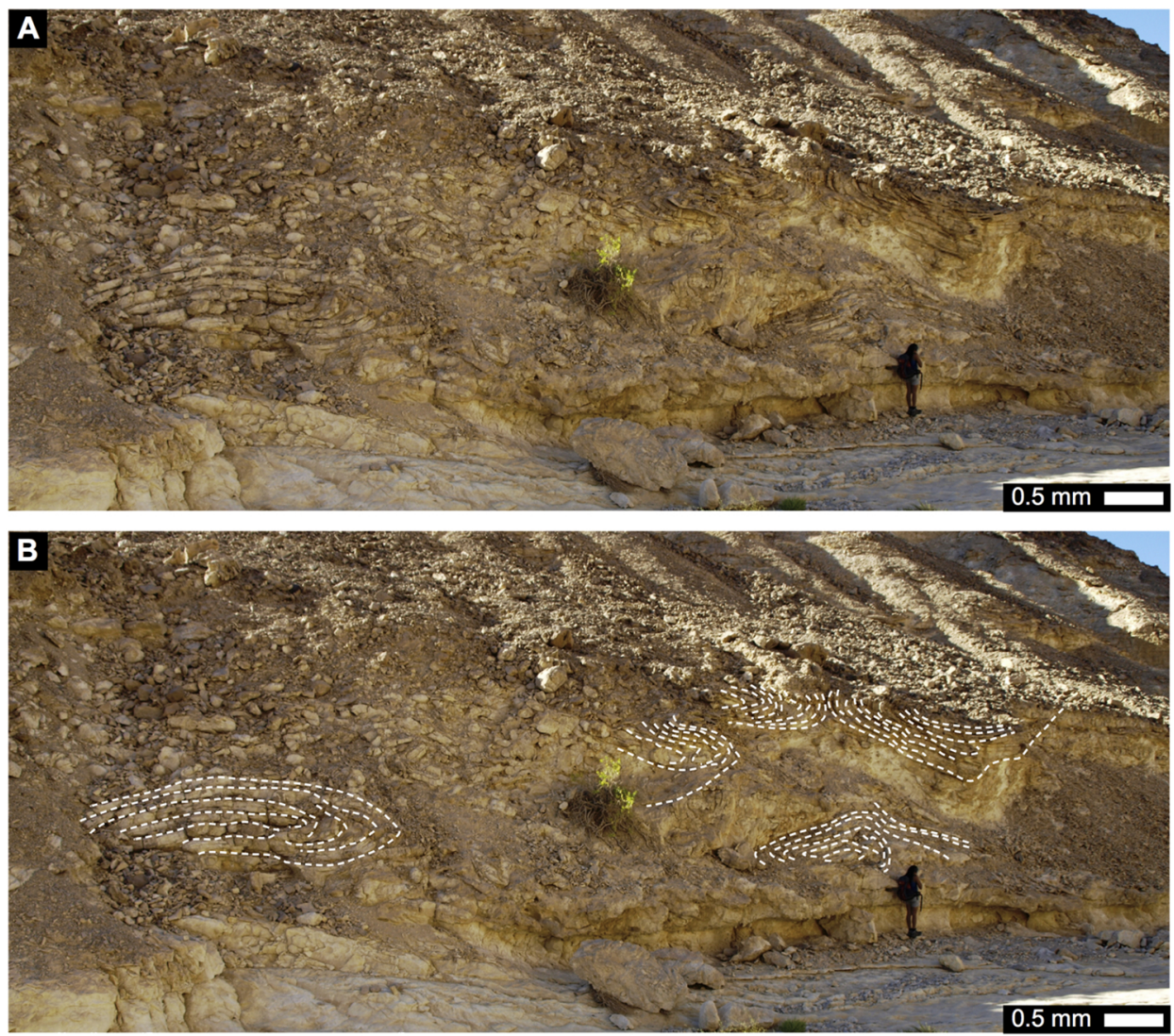

C

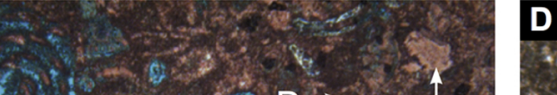

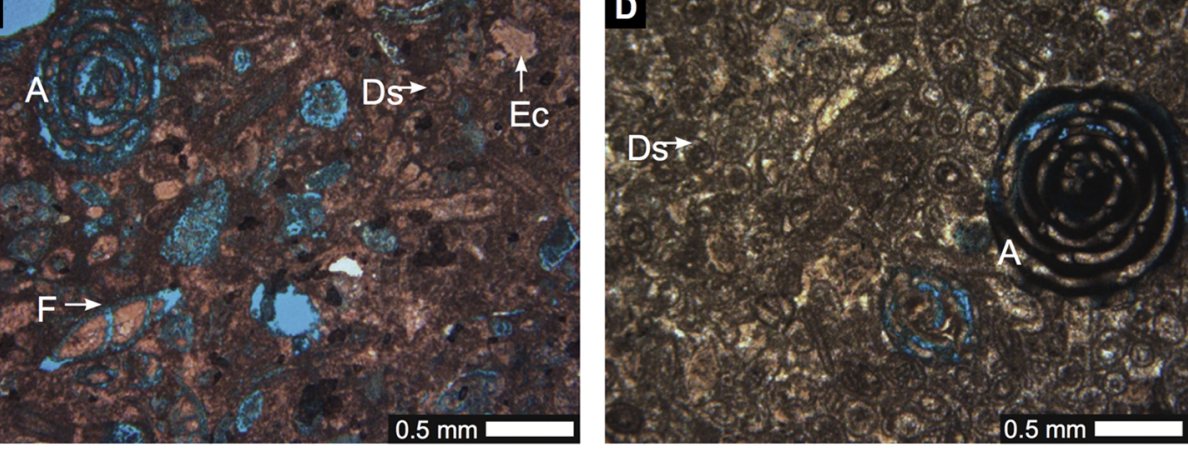

Dst

4h is

Figure 10 

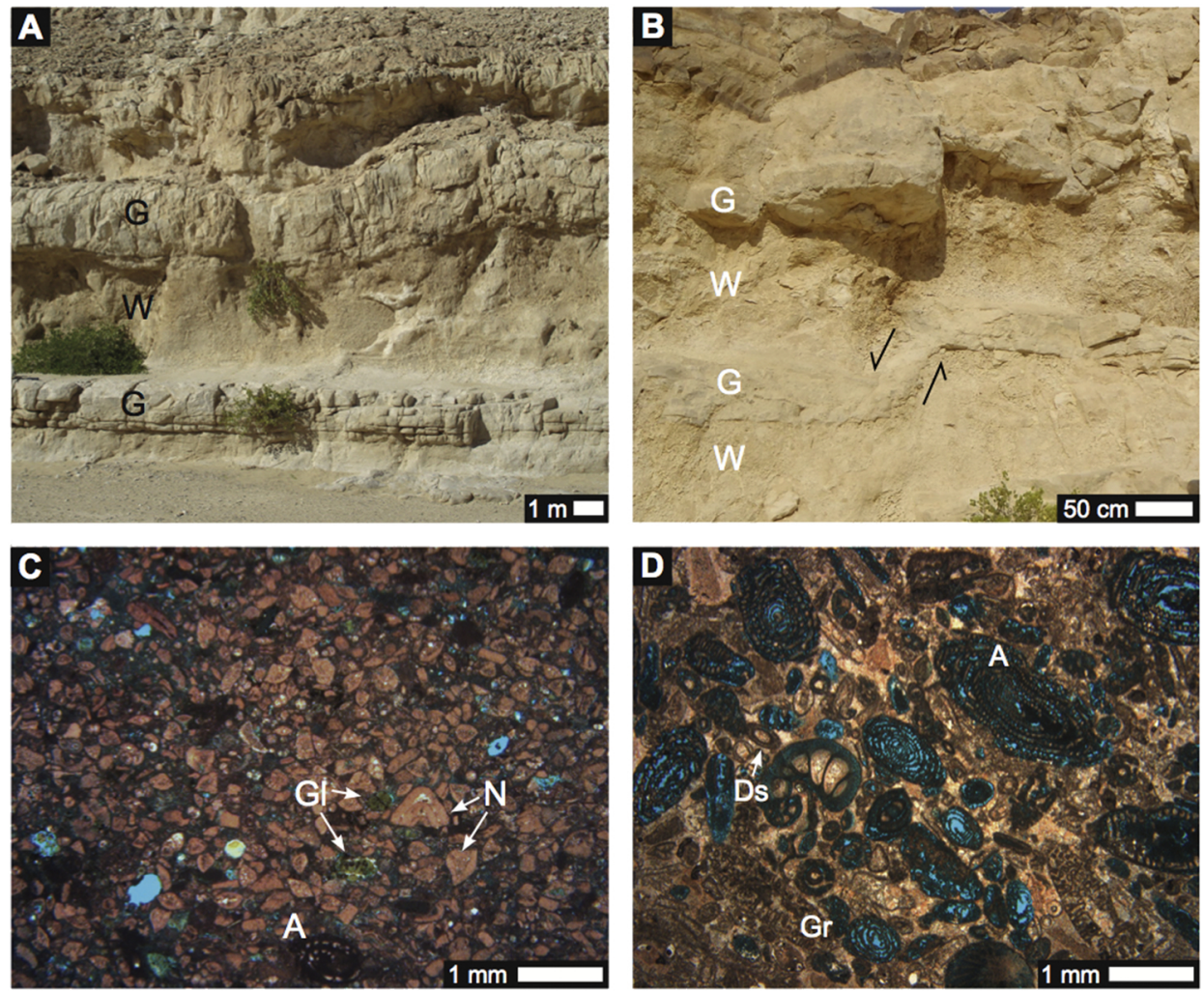

Figure 11 

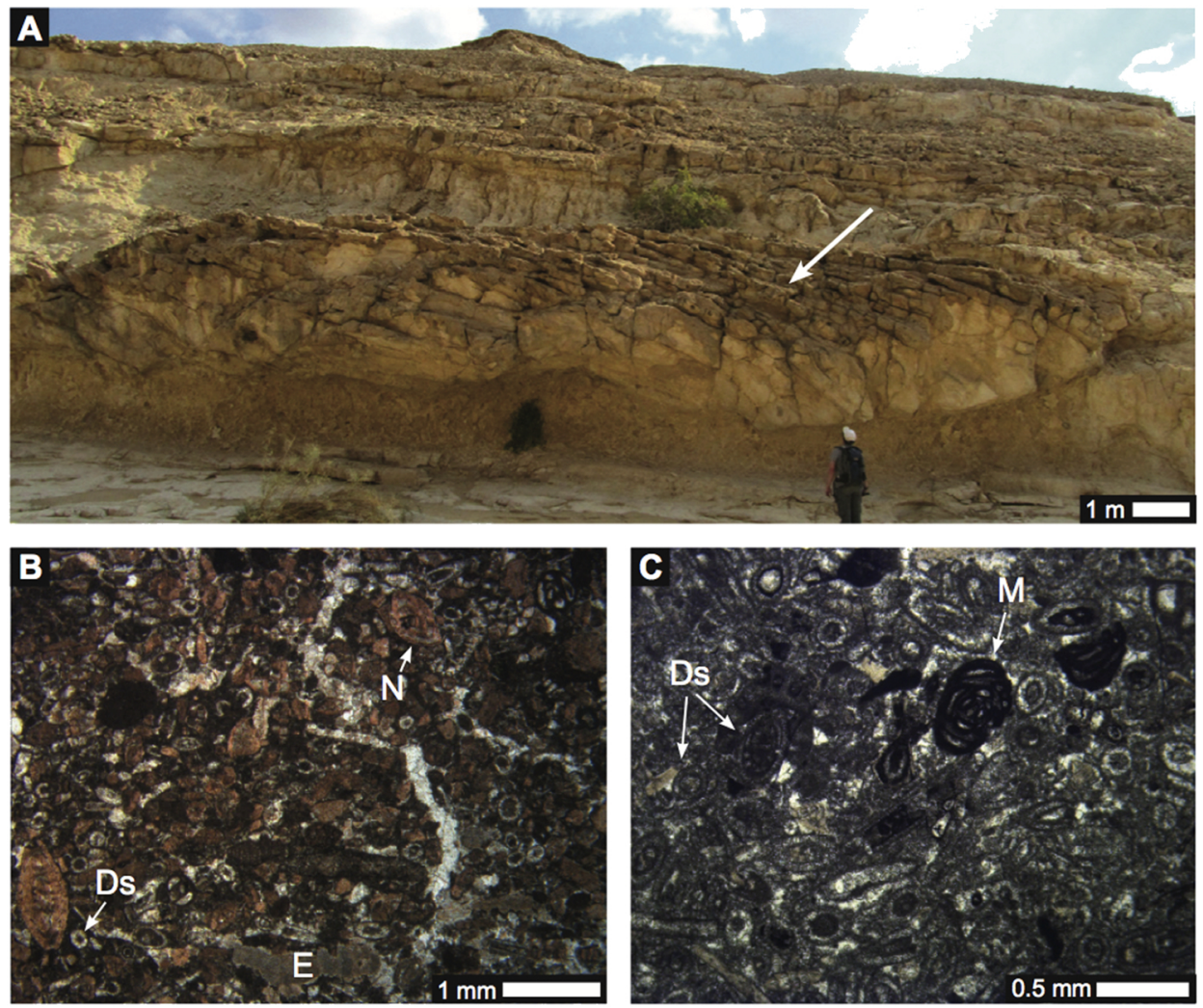

Figure 12 


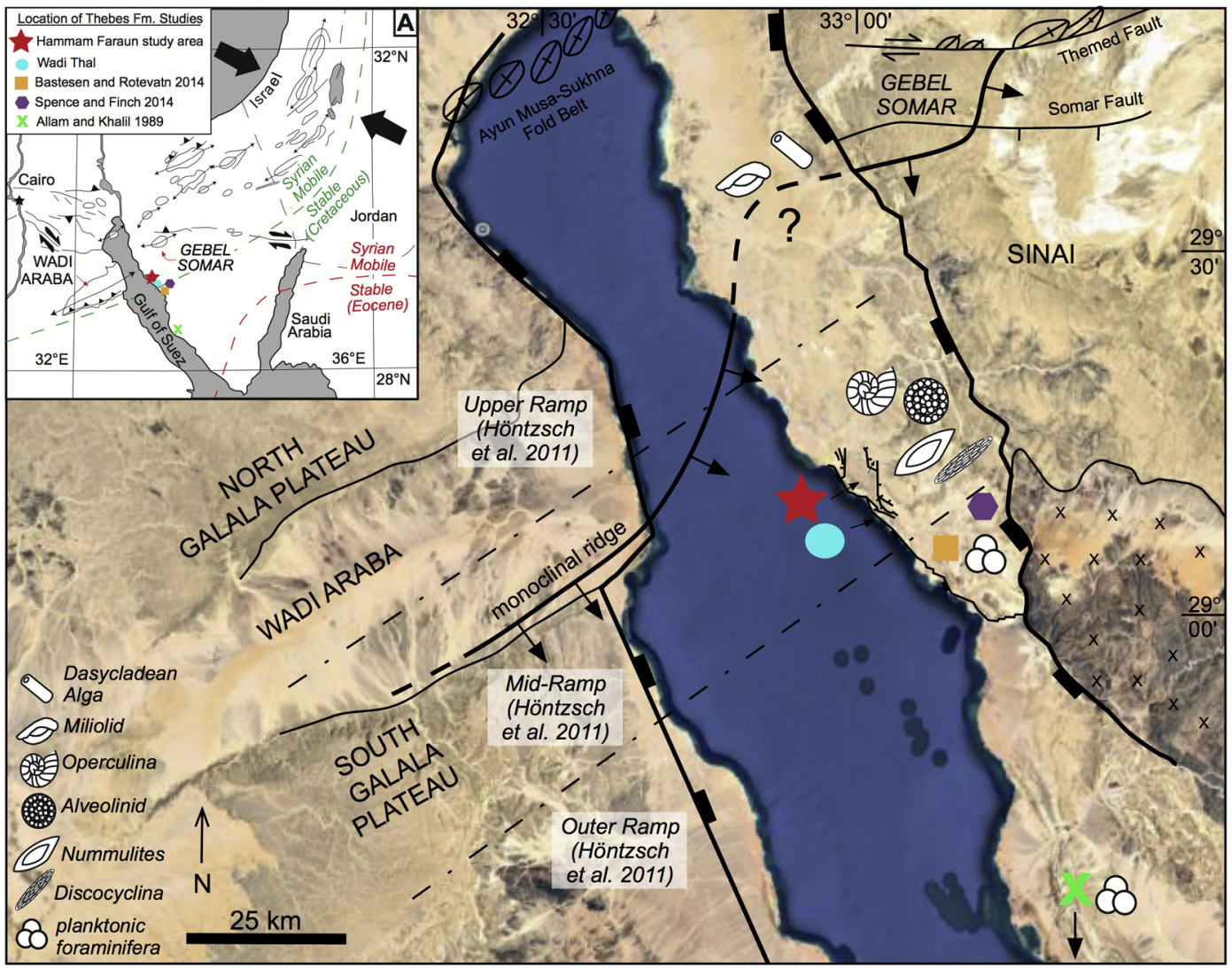

Figure 13 

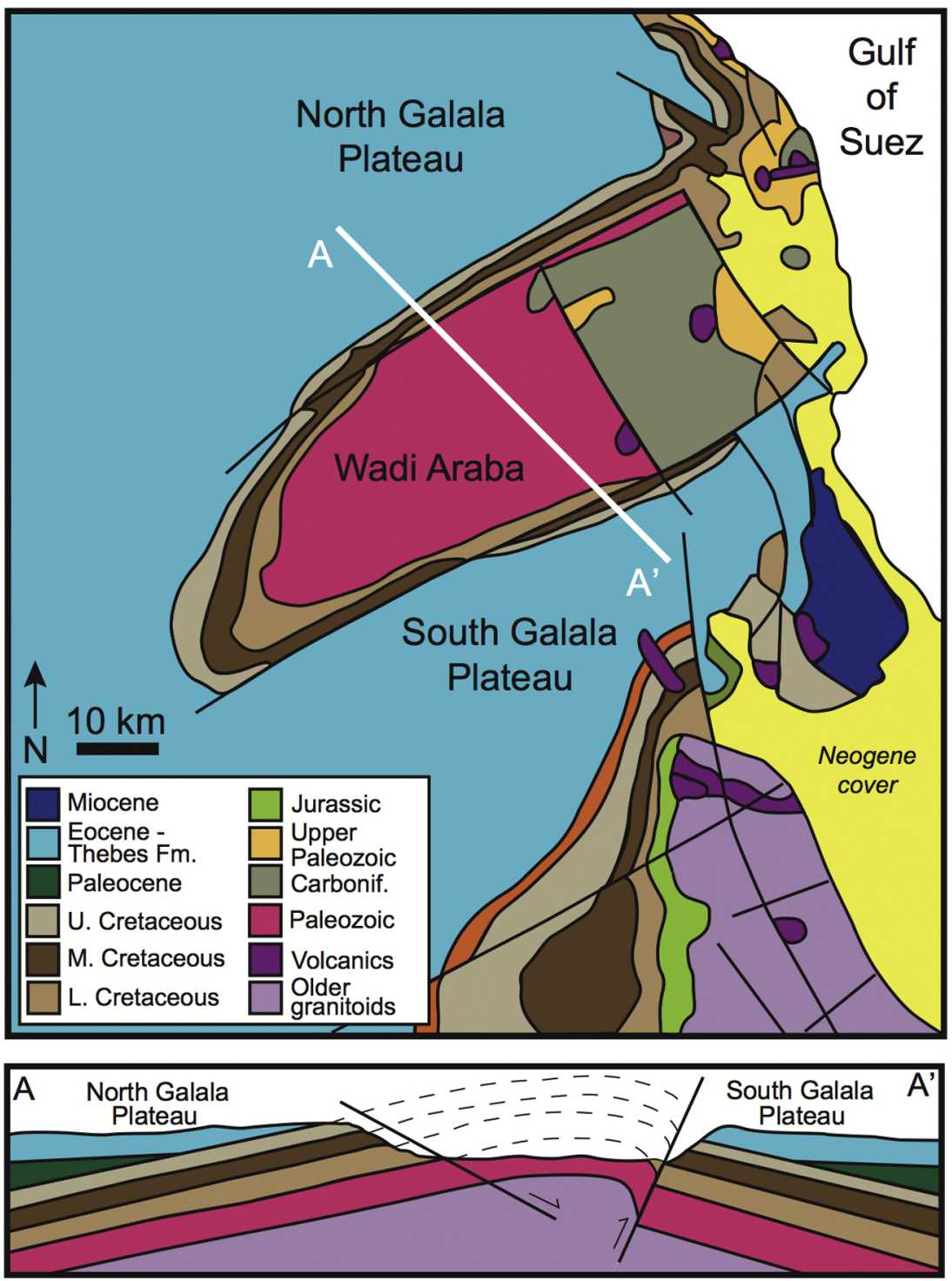